\title{
Toward a New Student Insurgency: A Critical Epistolary
}

\author{
Rachel Anderson \\ Marc-Tizoc González \\ Stephen Lee $\dagger$
}

\section{INTRODUCTION}

We decided to embark upon this collaborative correspondence in 2005, the year we graduated from the University of California, Berkeley School of Law (Boalt). We entered Boalt at a time of crisis in both the California and national public education systems. Locally, the state had taken over school districts for failing to achieve test scores required by the No Child Left Behind Act. ${ }^{1}$ In response, community leaders organized a historic march to the state capital and a hunger-strike that eventually caused the governor to accede to their demands that the state pay the school districts the funds to which an earlier proposition entitled them. ${ }^{2}$ Nationally, the Supreme Court decided the fate of affirmative action in the famous University of Michigan cases, resting its holding in favor of

Copyright $\odot 2006$ California Law Review, Inc. California Law Review, Inc. (CLR) is a Califomia nonprofit corporation. CLR and the authors are solely responsible for the content of their publications.

$\dagger \quad$ Rachel Anderson, J.D., 2005, University of California, Berkeley School of Law (Boalt Hall), A.M., 2002, Stanford University, Zwischenprüfung, 1998, Humboldt University, Berlin (email: lawpubs@gmail.com); Marc-Tizoc Gonzalez, J.D., 2005, University of Califomia, Berkeley School of Law (Boalt Hall), M.A., 2002, San Francisco State University, B.A., 1996, University of Califormia, Davis; and Stephen Lee, J.D., 2005, University of Califomia, Berkeley School of Law (Boalt Hall) M.A., 2001, University of California, Los Angeles; B.A., 1998, Stanford University. Special thanks to Professor Angela Harris for providing valuable fcedback on carly versions of this essay. We are indebted to Jamie Crook, Annisah Um'rani, Carol Garvan, and the other editors at the California Law Review for their thoughtful edits. We dedicate this essay to our compañeras/os at Boalt, our families, and to Marc-Tizoc's late father, Alfonso Z. González (Boalt Class of 1960), who was the first Mexican American to practice law privately in Sacramento, California and served thousands of Spanish-speaking clients for over forty years. He died on May 1, 2006.

1. No Child Left Behind Act of 2001, Pub. L. No. 107-110 (Jan. 8, 2002).

2. Patrick Hoge, Hunger Strike for School Funding, SAN Francisco Chron., May 11, 2004, at B5, available at http:/www.sfgate.com/cgi-bin/artiele.cgi?f=/c/a/2004/05/ 11BAG856JEF51.DTL\&hw=26+day+hunger+strike+forteducation\&sn=001 \&sc=1000; Dan Bacher \& Gail Ryall, Fast 4 Education at Calif. State Capitol, People's WeEkLy World, June 5, 2004, http://www.pww.org/artiele/view/5316/1/218/. 
affirmative action on the belief that a critical mass of social diversity is necessary to achieve educational excellence in higher education. ${ }^{3}$

Collectively and individually, the three of us embody some of the qualities that are commonly understood to represent social diversity. For example, in the dimensions of race and gender, one of us identifies as an African American woman of mixed racial heritage; another as an Asian American (Korean) man; and the other as a Chicana/o or xican@. ${ }^{4}$

We shaped this sociolegal essay in the form of a critical epistolary. We each wrote three letters that attempt to recreate the tone (intellectually vibrant, sometimes angry) and content of the many conversations after class, in cafes, over dinner, in the hallways, at public events, and behind the closed doors of the student organizations we shared with each other and many others while studying the law at Boalt from August 2002 to May 2005. In the course of these exchanges we became friends and political allies, in a word, compañeras/os. This epistolary examines the cyclical path of social justice activism at Boalt, deconstructs some weaknesses of social justice movements through a case study of the Asian American Movement, and identifies the revolutionary potential of the new student insurgency. We mean the fluid tone of our letters to reflect how we talk to each other, shifting easily between intimate conversation and critical discourse. ${ }^{5}$

In our letters, we use terms like "social justice," "social justice theory," "social justice praxis," and "social justice advocacy/activism."

3. Grutter v. Bollinger, 539 U.S. 306 (2003), aff'g 288 F.3d 732 (6th Cir. 2002). But see Gratz v. Bollinger, 539 U.S. 244 (2003).

4. By Chicana/o, Marc-Tizoc does not simply identify as being of Mexican ancestry and living in the United States. Instead he identifies as someone of indigenous and Mexican ancestry who is developing conocimiento-political and spiritual awareness. Moreover, he extends the convention of scholars affiliated with Chicana/o Studies and LatCrit theory, whose neologism, "Chicana/o," refutes the implied patriarchy of Spanish grammar, which holds that a plural word's masculine form subsumes the feminine. Marc-Tizoc pronounces Chicana/o as Chicana (with the "o" silent), to voice solidarity with radical feminism and Queer sexuality. $C$ f. infra note 98 . While pronouncing Chicana/o in this way and writing Chicanalo in the singular may confuse some people, it is intended to unsettle presumptions about gender and sexuality. In the San Francisco Bay Area, some young activists spell this word as "xican@," a neologism intended to distinguish the current generation of activists from earlier ones and also to incorporate knowledge about the grammar of Nahuatl, the language of the Mexica (Aztec) people, which reportedly is not gendered as Spanish and other Romance languages are. In this usage, a lower case " $\mathrm{x}$ " replaces the "Ch" to mimic the proper Nahuatl pronounciation, and the "@" sign replaces the "a/o" construction. For a detailed analysis of the legal adjudication of cases involving "accent discrimination" and thoughtful suggestions on how law might promote American linguistic pluralism, see Mari J. Matsuda, Voices of America: Accent, Antidiscrimination Law, and a Jurisprudence for the Last Reconstruction, 100 YALE L.J. 1329 (1991).

5. For other exemplars of the dialogic style that inspired us to collaborate on this "critical epistolary," see Robert S. Chang \& Adrienne D. Davis, The Adventure(s) of Blackness in Western Culture: An Epistolary Exchange on Old and New Identity Wars, 39 U.C. DAvIs L. REv. I189 (2006); Leslie Espinoza \& Angela P. Harris, Afterword: Embracing the Tar-Baby-LatCrit Theory and the Sticky Mess of Race, 10 La Raza L.J. 499 (1998); and Bell hooks \& Cornel West, Breaking Bread: Insurgent Black Intellectual Life (199I).

6. Social justice praxis can take on many forms in various contexts. In legal education, this can include taking a "consistent approach aimed at building memory, embracing identity, and fostering 
Our intent is not to promulgate a single definition of social justice, theory, practice, advocacy, movement, or activism. We do not fix operational definitions for these terms, because our experiences as friends and political allies persuade us that our personal definitions overlap sufficiently to justify our belief that we share common understandings of social justice and that we share a common journey toward its realization.

Our critical epistolary locates the activism of law students in contemporary social justice movements and traces these movements' histories by recording our own experiences as student activists. Though a growing body of work examines the relationship between law and social change, ${ }^{7}$ these works tend to incorporate and analyze the narratives espoused by liberalism. ${ }^{8}$ By contrast, the narratives and movements with which we are most intimately allied fall outside the mainstream and tend to be more transformative than reformist in nature. We thus hope to contribute to the rich, multifaceted and overlapping critical movements, the movements through which we met, shared, and aspired to change the world for the better.

Stephen Lee opens the epistolary by foregrounding Filipino farm worker and labor organizer Philip Vera Cruz's statement that leadership is only incidental to the movement, and then asking to what movements we were incidental as student leaders at Boalt. Rachel Anderson then responds by naming the importance of being our own Zeitzeugen, exercising the right to bear witness to our experiences by recording our insights about our communities and ourselves. She begins to tell a story about the history of social justice activism at Boalt, which she characterizes as simultaneously

agency among traditionally subordinated groups" and/or to "provide the knowledge base and analytical skills to "connect the dots' of the past and present in intellectual as well as personal terms." Francisco Valdes, Outsider Jurisprudence, Critical Pedagogy and Social Justice Activism: Marking the Stirrings of Critical Legal Education, 10 AsIAN L.J. 65, 75 (2003).

7. See Gerald N. Rosenberg, Positivism, Interpretivism, and the Study of Law, 21 LAw \& Soc. INQUIRY 435 (1996); Michael McCann, Causal versus Constitutive Explanations (or, On the Difficulty of Being So Positive ...), 21 Law \& Soc. InQuiry 457 (1996); William E. Forbath, Law and the Shaping of the American Labor Movement (1991); Robert C. Post \& Reva B. Siegel, Legislative Constitutionalism and Section Five Power: Policentric Interpretation of the Family and Medical Leave Act, 112 YALE L.J. 1943 (2003).

8. For purposes of this essay, Marc-Tizoc will use Will Kymlicka's definition of liberalism: "The defining feature of liberalism is it that ascribes certain fundamental freedoms to each individual. In particular, it grants people a very wide freedom of choice in terms of how they lead their lives." Will Kymlicka, Multicultural Citizenship: A Liberal Theory of MinOrity Rights 80 (1995). With regards to the rights of minorities specifically, Kymlicka elsewhere observes, "Liberals can only endorse minority rights in so far as they arc consistent with respect for the freedom or autonomy of individuals." Id. at 75. Robin L. West, Constitutional Skepticism, 72 B.U. L. REv. 765,774 (1992) ("What distinguishes progressives from liberals is that while liberals tend to view the dangers of an over-oppressive state as the most serious obstacle to the attainment of such a world, progressives, while agreeing that some obstacles emanate from the state, argue that for the most part the most serious impediments emanate from unjust concentrations of private power - the social power of whites over blaeks, the intimate power of men over women, the economic power of the materially privileged over the materially deprived.") (italics in original). 
linear and circular. Marc-Tizoc González then explains why he came to understand student activism at Boalt as part of a resurging social justice movement across the nation (and beyond) and develops his notion of the new student insurgency in U.S. law schools. Stephen replies by exploring the Asian American Movement, which responds both to Rachel's call to bear witness to local history and Marc-Tizoc's ruminations on radical student activism. Rachel then discusses the relationship between social crises and resurging waves of activism, continuing to narrate her story of student activism at Boalt. Marc-Tizoc replies by elaborating on the importance of law schools as politically contested sites of subject formation, not simply places where people are educated to become legal professionals, but rather social spaces that shape the basic ways in which society's new legal experts are taught to imagine and think about implementing "justice." Finally, we gyre toward the end of the epistolary with Stephen assessing the presence of the Asian American Movement at Boalt, Rachel focusing on Boalt students' activism in the sphere of legal scholarship and the tradition of bearing witness in an academic form, and Marc-Tizoc directing our attention beyond U.S. law schools to the world's apparent revolutionary moment of democracy and fascism.

Some letters discuss shared experiences from different perspectives; other letters focus on personal experiences, which we did not all share but which speak sufficiently to and for all of us. This is not a comparative analysis but rather an exercise in storytelling, braiding and sharing our overlapping experiences of education at Boalt. ${ }^{9}$ We call upon others to do the same, to represent their local histories of student activism amidst formal legal education, and to connect their experiences to the people's worldwide movement toward social justice.

I

LEADERSHIP IS INCIDENTAL TO THE MOVEMENT

(STEPHEN'S FIRST LETTER)

Dear Marc-Tizoc and Rachel,

I'm thrilled and grateful that we've been afforded the opportunity to exchange these letters with one another reflecting on our experiences at Boalt. As two of my closest friends and allies at Boalt, you have inspired me in the ways you both organized and moved your respectivc communities. I hope that others may benefit from our reflections on being friends as well as student intellectuals of color.

9. Critical race theory established legal storytelling as an important technique of sociolegal scholarship over twenty years ago. See, e.g., Richard Dclgado, Storytelling for Oppositionists and Others: A Plea for Narrative, 87 Mich. L. REv. 2411 (1989). 
As law students, we emerged as leaders within our communities. Collectively and individually, we poured hours of our lives into the Berkeley Journal of African-American Law \& Policy (BJALP) (formerly the African American Law \& Policy Report), the Asian American Law Journal (AAJL) (formerly the Asian Law Journal), Asian Pacific American Law Students Association (APALSA), Berkeley La Raza Law Journal $(B L R L J)$, La Raza Law Students Association (LRLSA), Law Students of African Descent (LSAD), the National Black Law Students Association (NBLSA), the National Latina/Latino Law Student Association (NLLSA), and the California Law Review (CLR), earnestly assuming both visible and covert positions of leadership. I list these student organizations to recognize that our law school experiences contributed to something larger than ourselves. As Filipino farm worker and labor organizer Philip Vera Cruz explained, "leadership . . . is only incidental to the movement."10

But if we are leaders, to what movements are we incidental?

In the letters that follow, I'd like for us to try and answer this question. Drawing on our personal experiences, I would like to outline the ways in which we as law students built, sustained, and were educated by various social justice movements. This exercise, I hope, will help counteract the unspoken assumption that law students must relinquish completely their connections to their various communities during their time as law students. Moreover, I hope our letters can clarify the term "social justice." "Social justice," along with several other important, contemporary ideas such as citizenship, equality, and discrimination, suffers for indeterminacy and thus leaves itself vulnerable to disingenuous cooptation. " By offering three different perspectives on the topic of social justice activism at Boalt, I hope we can better define this term.

Finally, these letters constitute a bundled gift to our beloved student organizations and journals. If nothing else, we are recording what we have witnessed so that others may avoid repeating our mistakes. Little institutional memory exists within our various student organizations. If we do not memorialize and evaluate the ways in which our student organizations succeeded or failed in bringing about change, we do a disservice to the broader movements at work.

Take good care,

Stephen

10. Glenn Omatsu, The 'Four Prisons' and the Movements of Liberation: Asian American Activism from the 1960s to the 1990s, in The State of Asian America: Activism and Resistance IN THE I 990 OS 59 (Karin Aguilar-San Juan ed., 1994).

11. See, e.g., Proposition 209, the so-called "California Civil Rights Initiative", recorded at, CAL. Const. art. 1, §31(a). 
II

\section{Twentieth Century Social Justice Movements and Boalt Hall} (RACHEL's First LETTER)

Dear Stephen and Marc-Tizoc,

I am pleased that we are taking this opportunity to bear witness to our experiences, record and preserve our insights about ourselves and our communities, be our own Zeitzeugen (contemporary witnesses), and perhaps make a small contribution to the movements and communities that have brought us this far. I use the term Zeitzeugen to mean bearing witness as part of a collective history in which we reflect on the social, political, and historical interconnections of our experiences. I feel honored to continue this Boalt tradition although throughout the process of writing this epistolary we have often been confronted with self-doubt and concerns about the value of our reflections and experiences.

Stephen, in your first letter, supra, you ask the question, "to what movements are we incidental?" I believe that the answer to this question goes to the heart of our goals in writing this epistolary. We are beneficiaries of, among others, the struggles to end segregation and prevent the resegregation of higher education, the Asian American Movement, resistance culture, global postcolonialism, the Civil Rights Movement, the end of slavery, and the Women's Movement. As beneficiaries and intellectual descendants of these and other movements, we write this epistolary in part as a form of status check, a consideration of where we are now, and what some of our generation of intellectuals are experiencing, responding to, and striving for in the context of legal education.

As the beneficiaries of these and other movements, we enjoy a level of access to academia that resulted from generations of struggle, and we are privileged to take this moment to publicly reflect on our experiences in the post-SPl, ${ }^{12}$ post-Proposition $209,{ }^{13}$ and post-affirmative action

12. On June 1, 1995, Governor Pete Wilson issued Executive Order W 124-95 titled "End Preferential Treatment and to Promote Individual Opportunity Based on Merit." Regents of the University of California, Current Policies, available at http://www.universityofcalifornia.edu/regents/ policies/spl.html (last visited Aug. 27, 2006). On July 20, 1995, the Regents of the University of California approved the "Policy Ensuring Equal Treatment Admissions" (SP-1) that, inter alia, abolished affirmative aetion in admissions at UC Berkeley. Id. SP-1 was rescinded on May 21, 2006. Id.

13. Proposition 209 is a voter initiative that amended and became part of the California Constitution, and took effect in January of 1998. CAL. Const. art 1, § 31(a). For discussions of the political environment and events leading up to the passing of the SP-1 Resolution and Proposition 209 in California as well as their effect at Boalt, see Andrea Guerrero, Silence at Boalt Hall: The Dismantling of Affirmative Action 67-109 (2002); Bob Berring, Affirmative Action in Perspective, 91 Calif. L. Rev. 1125 (2003) (reviewing Guerrero, supra); lan F. Haney López, Traditional Affirmative Action, 91 Calif. L. Rev. 1139 (2003) (reviewing Guerrero, supra); Amy DeVaudreuil, Silence at the California Law Review, 91 CALIF. L. REv. 1183 (2003) (reviewing Guerrero, supra); and Donna Maeda, Imperial Identities: Reproductions of Whiteness at the California Law Review, 
environment at a California public university. ${ }^{14}$ At the same time, we are three Boalt graduates of color writing at and about a time when the presence of students of color and the paths through which we may gain access to higher education are so hotly debated that the Supreme Court took two cases to rule on the issue. ${ }^{15}$

This crisis in access to higher education sparked a high-activity period of student social justice activism. This activism is not a new or isolated event but rather has its roots in, and shares many similarities with, earlier cycles of social justice activism at Boalt. In this letter, I trace some of the crises and responses at Boalt and highlight contradictions in the progression of achievements in social justice. In relating this history, I locate events at Boalt in the broader context of major socio-political events, civil rights cases, and national debates on diversity in higher education.

The concept of social justice is not new to legal education, although it has evolved since the concept first emerged in legal academia in the late nineteenth and early twentieth centuries. ${ }^{16}$ Crises are necessary preconditions for a shift in theory or practice, and they signal an opportunity and need to revise models and assumptions. ${ }^{17}$ Consequently, the role of social justice in legal education has changed and shifted in revolutionary ways in response to crises. ${ }^{18}$ This is true at Boalt as well and I would like to share some of what I have learned about the history of social consciousness at Boalt.

In the late nineteenth century, the crisis of social conditions in the industrializing world included slums, low wages, industrial accidents, industrial illness, poor housing conditions, poor urban planning, unsanitary conditions, domestic and child abuse, alcoholism, and prostitution, as well as fraud and abuse in the financial markets in the early part of the twentieth

http://bobcat.cc.oxy.edu/ maeda/clr.htm (last visited Feb. 23, 2006). Andrea Guerrero (Boalt Class of 2000), Amy DeVaudreuil (Boalt Class of 2004), and Donna Maeda (Boalt Class of 2003) are Boalt alumni. lan F. Haney López and Bob Berring (Boalt Class of 1974 and Interim Dean from January 2003 to June 2004) are both currently professors at Boalt.

14. For a discussion of the effects on admissions and enrollment at Boalt, see Ryan Fortson, Affirmative Action, the Bell Curve, and Law School Admissions, 24 SEATtLE U. L. REv. 1087, $1114-16$ (2001) (discussing the decreasing numbers of applications and admissions of students of color compared to the increase of applications from White students) and MiCHAEL K. BROWN ET AL., Whitewashing Race: The Myth of a Color-Blind Society 269 n. 127 (2003) (discussing the drop in enrollment of Black and Latino/a students).

15. Grutter v. Bollinger, 539 U.S. 306 (2003), aff'g 288 F.3d 732 (6th Cir. 2002); Gratz v. Bollinger, 539 U.S. 244 (2003).

16. See generally Duncan Kennedy, Professor, Harvard Law Sch., The Social Justice Element in Legal Education in the United States, Sir Elwyn Jones Lecture at the University of Wales at Bangor (Mar. 19, 2002), in I UNBOUND 93 (2005), available at http://www.law.harvard.edu/students/ orgs/unbound/articles/IUNB093-Kennedy.pdf (discussing the role of social justice in legal education over the past 100 years).

17. See Thomas S. Kuhn, The Structure Of Scientific Revolutions 76-77 (1996).

18. See id. at 12. 
century. ${ }^{19}$ These crises forced legal theory to respond to the changing social conditions resulting from industrialization. Also during this time, the Jurisprudence Department at UC Berkeley moved to new housing in the Boalt Hall School of Law. Boalt opened its doors on January 17, 1911, approximately thirty years after the first law course was taught on the Berkeley campus, ${ }^{20}$ and the same year that William Henry Lewis was confirmed as Assistant Attorney General of the United States, becoming the first Black to hold a high office in the Justice Department. The law department was to be "dedicated to the education of those whose lives shall be devoted to the giving of equal chances to all." ${ }^{21}$ However, even as the law department transformed into a more autonomous law school $^{22}$ to address the increasing demand for law reform, the objectives for the law school included "provid[ing] trained men for the administration of our [c]olonial possessions." 23 Thus, from a decolonialized post-Third World Movement perspective, the law school's early objectives reveal inherent contradictions.

Nonetheless, the early years at Boalt revealed a commitment to social justice. In 1915, the same year the U.S. Supreme Court declarcd the grandfather clauses of the Maryland and Oklahoma constitutions repugnant to the Fifteenth Amendment, ${ }^{24}$ the law school played an important role in the creation of the Legal Aid Society of San Francisco (although it should be noted that student participation was not encouraged at that time). ${ }^{25}$ The importance placed on social issues can also be seen in the 1919 appointment of Barbara Nachtrieb Armstrong (Boalt Class of 19I5), the first woman appointed to a full-time faculty position at a major American law school, as a lecturer in Iaw and social economics. ${ }^{26}$

Also in the early twentieth century, student activism prompted the establishment of CLR in August 1911. ${ }^{27}$ CLR aimed to fill the need for a "periodical in which lawyers, legislators, and teachers could express themselves extensively and freely, could exchange thoughts, and could record the history and development of western law."28

19. See id. at 96.

20. Sandra P. Epstein, law at Berkeley: The History of Boalt Hall 60 (1997).

21. Id. at 61 (internal citation omitted).

22. In August of 1912, the Department of Jurisprudence was admitted to the Association of American Law Schools and on November 12, 1912; it was subsequently renamed the School of Jurisprudence. $l d$. at 65-66.

23. Id. at 63 (citing Committee Report, Dep't of Jurisprudence (Jan. 26, 1910) (included in minutes of faculty meeting)).

24. Guinn v. U.S., 238 U.S. 347 (1915) (striking down a "grandfather clause" exempting the descendants of pre-Civil War voters from a literacy test).

25. EPSTEIN, supra note 20 , at 81 .

26. Id. at 84 .

27. Id. at 67 .

28. Id. at 68 (discussing Professor O.K. McMurray's introductory note in the first issue of $C L R$ ). McMurray was Dean of Boalt Hall from 1923 to 1936. 
$C L R$ also has several firsts to its credit, including the selection of Esther B. Phillips as editor-in-chief in 1917, the first female leader of any American law review. ${ }^{29}$ It should be noted that Phillips's selection took place during World War I, an era when many women gained access to opportunities because many men were serving on active military duty. I write this not to question Phillips's qualifications but rather to highlight that the crisis of World War I led to a revision of models and assumptions and a subsequent shift in traditional practice. In the same year $C L R$ selected Phillips as editor-in-chief, Walter A. Gordon (Boalt Class of 1922) became the first Black student to attend Boalt, and the U.S. Supreme Court invalidated a Louisville, Kentucky housing segregation ordinance. ${ }^{30}$

The interim period between the two World Wars was also a period of heightened social change. During this time, Jasper Alston Atkins, Charles Hamilton Houston, and Edwin Taylor became the first Black students to work on a law review. Five years later, Clara Burrill Bruce became the first Black woman on a law review, and then became the first Black editor-inchief of a law review a year later. While Boalt was progressive in some areas, CLR did not elect its first Latina and Black editors-in-chief until 2002 and 2006 , respectively. ${ }^{31}$

Important social changes continued before and during World War II. Black Boalt alumni such as George M. Johnson (Boalt Class of 1929) began taking on leadership roles throughout the legal profession. In 1940, Johnson joined the faculty at Howard University Law School (one year before Sadie T.M. Alexander became the first Black woman to publish in a bar journal) and two years later Johnson served as Deputy Chairman and General Counsel of the U.S. Committee on Fair Employment Practice. On the access front, the U.S. Supreme Court invalidated state laws requiring Black students to attend out-of-state schools rather than be admitted to allWhite schools in their states, a holding that was used as a tool to compel Southern universities to give Black graduate students the same opportunities as Whites. ${ }^{32}$

Between the two World Wars, students of color remained underrepresented at Boalt. It is difficult to compile complete and accurate demographic records, in part because ethnicity identification often must rely on surnames or alumni and faculty recollections. However, it seems that up through the start of World War II, Boalt had enrolled a total of

29. However, to my knowledge, it was not until much later that $C L R$ elected as editor-in-chief its first woman of color, a Latina (2002), its first openly gay man (2004), and its first African American, a man (2006).

30. Buchanan v. Warley, 245 U.S. 60 (1917).

31. These firsts are based on my personal knowledge. Unfortunately, recorded information on these facts is spotty and CLR does not allow access to its records. I would be happy to be corrected and learn that there were earlier firsts of which 1 am not aware.

32. Missouri ex rel. Gaines v. Canada, 305 U.S. 337 (1938). 
twelve students with Asian surnames (two Chinese and ten Japanese) and seven students with Spanish surnames, and up through 1968, it had enrolled approximately eighteen Black students. ${ }^{33}$

During World War II, Boalt's faculty and CLR failed to address the complex social and legal issues raised by the forced relocation of Japanese citizens. While the jurisprudence faculty may have questioned the legality of the government's actions behind closed doors, "records of statements or writings in other publications by the faculty" were quiet on the issue despite the considerable presence of Japanese Americans in California. ${ }^{34}$ This issue touched the law school directly, as indicated by minutes of faculty meeting discussions regarding whether to grant credit for partial semester work for a second-year student who was "evacuated as a Japanese. $"{ }^{.35}$

The post-World War II period saw the continued reform of access to legal education through targeted litigation strategies, but tensions surrounding social justice in practice also began to mount. Black Boalt alums made significant contributions to the legal academy during this time, including Pauli Murray (Boalt Class of 1945), who became the first Black attorney to publish in an academic law review, ${ }^{36}$ thirty-six years after $C L R$ was established and twenty-six years after the first Black law student graduated from Boalt. In 1950, the U.S. Supreme Court held that a Black student admitted to a formerly all-White graduate school could not be subjected to practices of segregation that interfered with meaningful classroom instruction and interaction with other students; ${ }^{37}$ that same year the Court also held that a law school hastily established for Black students to prevent their admittance to the all-White University of Texas School of Law could not provide a legal education "equal" to that of White students. ${ }^{38}$ Four years later, and one year before Black Boalt alum Walter Gordon was appointed Governor of the U.S. Virgin Islands and received the California Alumnus of the Year Award, the U.S. Supreme Court overturned the "separate but equal" doctrine underpinning legal segregation, by ruling that racial segregation in public schools violated the Fourteenth Amendment. ${ }^{39}$ In the following five years, Rosa Parks' famous arrest launched the Montgomery Bus Boycott, the U.S. Supreme Court

33. Law Students Of African Descent, Black History Month Booklet 33-36 (2003) [hereinafter LSAD]. However, the list that we were able to reconstruct for the Law Students of Afriean Descent Black History Month booklet lists less than a third of this number for the period up through World War II.

34. EPSTEIN, supra note 20, at 160.

35. Id. at 181 (eiting Minutes of Faculty, Sch. of Jurisprudence (Apr. 16, 1942)).

36. Pauli Murray, The Right to Equal Opportunity in Employment, 33 CALIF. L. Rev. 388 (1945).

37. McLaurin v. Okla. State Regents, 339 U.S. 637 (1950).

38. Sweatt v. Painter, 339 U.S. 629 (1950).

39. U.S. CoNST. amend. XIV. 
declared city bus segregation laws unconstitutional, ${ }^{40}$ the Supreme Court barred interference with the desegregation of Little Rock's Central High School, ${ }^{41}$ Walter Gordon was appointed to the District Court of the Virgin Islands, and Professor Sho Sato became the first Asian American member of the Boalt faculty. Professor Sato was also the first Asian American to become a professor at a major American law school. ${ }^{42}$ Appointed in 1951, sixty-nine years after the first law course was taught on the Berkeley campus, Professor Sato joined as the first minority member of the Boalt faculty. ${ }^{43}$ Boalt's Sho Sato Program in Japanese and U.S. Law and its annual conference bear his name.

In the 1960s and 70s, sociopolitical movements such as the Civil Rights movement, ${ }^{44}$ the Free Speech Movement, and the Third World Movement signaled mounting social crises. In 1964, fifty-two years after Boalt became an accredited law school, Professor John Robinson Wilkins, ${ }^{45}$ General Council of the U.S. Agency for International Development and recipient of the Arthur S. Flemming Award for excellence in government service, was hired as the first Black member of the Boalt faculty. That same year, Free Speech Movement supporters became active at UC Berkeley, and although law students were not heavily involved initially, Boalt faculty became very involved early on. For example, Professor Richard Buxbaum (Boalt Class of 1953) "was one of the five defense counsel in the criminal proceedings against the 773 members of the Free Speech Movement from 1964 to $1967^{\prime \prime}$ and "represented various campus organizations and individuals in cases arising

40. Gayle v. Browder, 352 U.S. 903 (1956).

41. Cooper v. Aaron, 358 U.S. 1 (1958).

42. EPSTEIN, supra note 20, at 279.

43. In the decades that followed, a few professors of color joincd the Boalt faeulty. 1 am aware of seven professors of Afriean descent through 2005: John Robinson Wilkins, appointed in 1964, Henry Ramscy (Boalt Class of 1963), appointed in 1971, James Crawford in 1979, Angela Harris and Bryan Ford in 1988, Norman Spaulding in 2000, and Melissa Murray in 2006. 1 am aware of only three Latinas/os: Rachel Moran appointed in 1983, Dan Rodriguez in 1988, and lan Haney-Lopez in 1996. 1 am aware of five faculty inembcrs of Asian descent: Sho Sato appointed in 1951, Marina Hsieh and John Yoo in 1993, Stephen Choi in 1998, Goodwin Liu in 2003, and Leti Volpp in 2005. Of these, lan Haney-Lopez, Angela Harris, Goodwin Liu, Raehel Moran, Melissa Murray, Leti Volpp, and John Yoo are currently on the Boalt faculty. To my knowledge, Boalt has never appointed a Native American faculty member.

44. The Letter From a Birmingham Jail, written by Martin Luther King, Jr. after his arrest for demonstrating without a permit, was the first assigned reading in my Civil Procedure I class taught by Professor Norman Spaulding, one of the two Black faculty members at Boalt when 1 was a first year law student.

45. Representative of the backlash after the initial wave of dcsegregation and increased opportunities and access for Blacks, Wilkins was the fourth Black student to become a member of the Harvard Law Review and was also the last Blaek student to become a member of that review until Christopher F. Edley, Jr. (Dean of Boalt since 2004) became a member. David B. Wilkins, Charles Hamilton Houston and the Nobler Traditions of the Harvard Law Review, Harvard Law Bulletin (1998), http://www.law.harvard.edu/alumni/bulletin/backissues/summer98/article4a.html. 
out of Vietnam War protests." 46 He served as "defense counsel in a large number of criminal proceedings that accompanied the Third World Strike of 1969-70"; this strike "was a factor in the development of affirmative action programs for student admissions on the Berkeley campus." ${ }^{\prime 47}$

Affirmative action, abolished a few years before we came to Boalt, had its roots in two executive orders. Executive Order 10925, issued by President John F. Kennedy, created the Committee on Equal Employment Opportunity and mandated that projects with federal funds "take affirmative action" ${ }^{\text {"48 }}$ to ensure that hiring and employment practices were free of racial bias. Executive Order 11246, issued by President Lyndon B. Johnson, enforced affirmative action for the first time and required government contractors to "take affirmative action" 49 in the form of specific measures to ensure equality in hiring, and to document such efforts.

Students, and particularly students of color, began demanding more dramatic changes to the law school curriculum, ${ }^{50}$ and during the 1960 s and 70 s, law schools, including Boalt, made further changes in response to their demands. Schools added courses that focused on the role of law in public policy decisions in relation to the needs of individuals and society. Boalt offered new courses such as Correction and Sentencing; Slavery as an American Legal Institution; a Consumer Protection Seminar; Children and the Law; Patterns in Collective Bargaining; and Civil Disobedience, Self Help, and Coercion. ${ }^{51}$ Fulfilling these demands to change the curriculum required new kinds of scholarship.

Furthermore, the resulting "increased number of minority students at Boalt had an appreciable effect on the law school. For the first time in its history, the norms and assumptions underlying the historically White male institution came under fire." 52 The burgeoning student of color population, the enrollment of Free Speech Movement supporters, and student involvement in the Third World Liberation Front all increased awareness of racial issues. ${ }^{53}$

46. School of Law - Boalt Hall, Faculty Profiles, Richard Buxbaum, http://www.law.berkeley.edu/faculty/profiles/facultyProfile.php? faclD=17 (last visited Oct. 23, 2006).

47. Id.

48. Exec. Order No. 10925, 26 Fed. Reg. 1977 (Mar. 6, 1961).

49. Exec. Order No. 11246, 30 Fed. Reg. 12319 (Sept. 24, 1965).

50. See Guerrero, supra note 13 , at 15 (citation omitted).

51. See id. at 16 (citing Interview by Andrea Guerrero with Robert Cole (Sept. 22, 1999)); EPSTEIN, supra note 20, at 267

52. GUERRERO, supra note 13 , at 15 .

53. Id. at 17 (citing Interview by Andrea Guerrero with Edward Halbach (Apr. 18, 2000) (stating "Dean Edward Halbach, who had led the development of a formal affirmative action program at Boalt, recalled ... ' $[t]$ he more minorities there were around and the more comfortable they became, the more we understood the extent and complex nature of racial problems in our society."'). 
Boalt students participated in a broad range of social justice and "race plus" practices, used by Professor Sumi Cho (Boalt Class of 1990) and Professor Robert Westley (Boalt Class of 1992) to "designate the centrality and historicity of race-based organizing that recognized a network of oppressions and embraces coalitional consciousness and solidarity with other outsider groups." 54 The Boalt Hall Community Assistance Program coordinated student activism. Its activities included draft counseling, welfare appeals, legal assistance for Native Americans in California, teaching legal concepts to minority high school students, a rural legal assistance program, and protesting the United States' invasion of Cambodia. ${ }^{55}$ Students also worked closely with faculty on administrative issues. ${ }^{56}$ One formal example of this collaboration was the Faculty-Student Coordination Committee. ${ }^{57}$

In addition, the increasing diversity of Boalt's student body meant that student interests were less homogenous. As a result, groups began to form that focused on specific issues such as race, gender, and access rather than on the issues traditionally of interest to the young, White, class-privileged males who had formerly dominated the law student population. Students of color and allied White students began to question the underrepresentation of students of color at Boalt.

The post-1960s period witnessed a proliferation of methodologies and ideologies including technical economics, liberal political philosophy, Marxism, feminism, empiricism, critical legal studies, neopragmatism, and postmodernism. ${ }^{58}$ Among many other sociolegal insights, these theories highlighted the artificial nature of binary oppositions such as male/female, Black/White, rich/poor, and heterosexual/homosexual, and signaled the need for a non-dualistic theory of social justice.

These earlier social movements yielded a faculty and student body with a diversity of backgrounds and interests, and produced some members willing to publicly critique the dismantling of affirmative action through Proposition $209 . .^{59}$ Students and faculty opted to speak out, ${ }^{60}$ and they

54. Sumi Cho \& Robert Westley, Historicizing Critical Race Theory's Cutting Edge: Key Movements That Performed the Theory, in Crossroads, Directions, And A New Critical Race THEORY 34 (Francisco Valdes et al. eds., 2002) [hereinafter Cho \& Westley, Historicizing]; Sumi Cho \& Robert Westley, Critical Race Coalitions: Key Movements that Performed the Theory, 33 U.C. Davis L. Rev. 1377, 1385 (2000) [hereinafter Cho \& Westley, Critical Race] ("designat[ing] the centrality and historicity of race-based organizing that recognized a network of oppressions and embraces coalitional consciousness and solidarity with other outsider groups").

55. EPSTEIN, supra note 20, at 272.

56. Id.

57. Id.

58. Kennedy, supra note 16 , at 101 .

59. I should note that, through students' storytelling to retain institutional memory, I learned that not all of the Boalt faculty denounced Proposition 209; some supported the elimination of affirmative action. 
continue to respond to the issues raised and ignored by Proposition 209..$^{61}$ To use the words of Boalt Professor lan F. Haney López in 2003, members of the Boalt community "ma[d]e some noise." 62

I am pleased that we have taken this opportunity to pass on this institutional memory to future generations so that they may be aware of the past, and so that they can more effectively shape the future.

\section{Sincerely,}

Rachel

\section{III}

The NeW STUdent INSURGENCY (MARC-Tizoc's First LetTER)

Querida/o Rachel y Stephen,

I share your delight in this opportunity to record our understandings of student activism at Boalt, to reflect on the movements to which we are incidental, and to learn more of Boalt's oft-occluded history of social justice. ${ }^{63}$ In this letter I hope to explain what I came to believe in our final

60. See, e.g., Berring, supra note 13; Cho \& Westley, Critical Race, supra note 54; Haney López, supra note 13; Marjorie M. Shultz, Excellence Lost, 13 BeRKELEY Women's L.J. 26 (1998); ALPR Editors \& La Raza Editors in Mary Louise Frampton, Foreword, Collaboration: The True Spirit of Brown v. Board of Education, 6 AFR.-AM. L. \& PoL'y Rep. 128, 129 (2004) [hereinafter Foreword]; Marisa Arrona, Alegría De La Cruz \& César del Peral, From Michigan to Cincinnati: Our Fate in their Hands, 13 Berkeley LA Raza L.J. 103 (2002); Marisa Arrona \& César del Peral, Introduction, 12:2 Berkeley LA Raza L.J. (2001) (unpaginated); Sarah H. Bond \& Erin K. Pitts, Editors' Note, 6:1 Afr.-AM. \& Pol'y ReP. (2004) (unpaginated); Commentary, Boalt Hall in a Post-Affirmative Action Era, 13 BeRKeley Women's L.J. 1 (1998) [hereinafter Commentary]; Jessica Marie Delgado, The Courage I Know, 13 Berkeley WoMEN's L.J. 7 (1998); Guerrero, supra note 13; Kaaryn Gustafson, Broken Promises, 13 Berkeley Women's L.J. 3 (1998); Alma Lagarda \& Luz C. Valverde, Introduction, 15:1 BerKeley LA RAZA L.J. (2004) (unpaginated); Araceli Martínez-Olguín, $A$ Redefining Moment, 13 BERKELEy LA RAZA L.J. 109 (2002); Erick Muñoz, Off to See the Wizard, 13 Berkeley la Raza L.J. 111 (2002); Cristina Perez \& Mike Smith, Introduction, 11:2 La Raza L.J. (1999-2000) (unpaginated).

61. Volume three of $A L P R$ was published under the shadow of the academic year marking "the end of Affirmative Action at the University of California[,] . . Berkcley[,] and the admittance of the members of the 'color-blind' class of 2000." Editors' Note, 3 Afr.-AM. L. \& Pol'y REP. (1997) (unpaginated). The 1997 Editors expressed their concern that "our once diverse institution is soon at an end, and with it, our cultural law journals." Id.

62. Haney López, supra note 13, at 1147 . In response to the loss of external support we began to turn inward to our communities and to build interracial coalitions for intellectual exchanges. We were inside and we would make changes from within. For a discussion of outsider scholars and OutCrit perspectivity, see generally Francisco Valdes, Outsider Scholars, Critical Race Theory, and "OutCrit" Perspectivity: Postsubordination Vision as Jurisprudential Method, in Crossroads, supra note 54. To some extent, we had a sense we did not need external listeners to validate and legitimize our thoughts, perspectives, and work. If we in our communities believed it was of value, then this was sufficient.

63. When 1 use the term "understanding," 1 follow the usage of George Martinez. See George A. Martínez, Latinos, Assimilation and the Law: A Philosophical Perspective, 20 ChiCano-Latino L. 
year at Boalt: that at our best we acted like insurgents, people who resist identifying with the dominant power and who rebel ethically against it, as we engaged the critical race coalition work that marked our three years of studying the law. ${ }^{64}$

To me, naming student activism in the dawning twenty-first century an insurgency evokes some of the most compelling features of the emerging shift in social justice theory and practice, in particular its critical race praxis. ${ }^{65}$ For law students, insurgent student activism involves creatively fusing critical study of the law, with dedicated practice in a clinical legal education program, and coalitional interventions within the law school itself. Instead of accepting distance from the local community, an insurgent student activist seeks to engage the community as a valuable

REV. 1, 22 (1999) (“By 'understanding' Heidegger 'means taking a stand on.' In selecting a specific activity, "wc take a stand on our own being." (internal citations omitted). This active usage highlights our living relationship to knowledge and each other and seems especially sensible after reading works by insurgent Black philosopher Bell Hooks and Chicana lesbian feminists like Gloría Anzaldúa. See, e.g., Bell hooks, Killing Rage: Ending RaCism (1995); Gloria AnZaldúa, Borderlands: La Frontera (1987). Beyond rehabilitating Eurocentric philosophy for present purposes, Martínez encourages "Latinos, African-Americans, Asian-Americans and Native Americans [to] establish an epistemic coalition to achieve knowledge about [our]sclves and [our] place in the world." George A. Martínez, African-Americans, Latinos, and the Construction of Race: Toward an Epistemic Coalition, 19 Chicano-Latino L. Rev. 213, 222 (1998). I believe our epistolary manifests that spirit.

64. By "critical race coalition work," I refer to people's organized attempts to work together across racial divisions and with critical understandings of race and other dimensions of power and identity. On the importance of critical race coalitions for creating sustainable interracial justice, see, for example, Cho \& Westley, Critical Race, supra note 54, at 1380-1405 (recounting the history of student activism at the University of California, Berkeley, in the latter half of the twentieth century and explaining how local student movement at Boait Hall inspired student activism at other law schools across the nation).

65. Eric K. Yamamoto (Boalt Class of 1978) conceived critical race praxis as combining "critical pragmatic socio-legal analysis with political lawyering and community organizing for justice practiced by and for racialized communities ... justice is something experienced through practice. Critical Race Praxis: Race Theory and Political Lawyering Practice in Post-Civil Rights America, 95 Mich. L. Rev. 821, 829-30, 873-80 (1997) [hereinafter Yamamoto, Critical Race Praxis]; see also Robert A. Williams, Jr., Vampires Anonymous and Critical Race Practice, 95 MicH. L. REv. 741, 760-65 (1997) ("Critical Race Practice is mostly about learning to listen to other people's stories and then finding ways . . . to make them matter through community institution building."); and Eric K. Yamamoto, Rethinking Alliances: Agency, Responsibility and Interracial Justice, 3 ASIAN PAC. AM. L.J. 33 (1995). Note that unlike Eric Yamamoto, I do not exclude people racialized as White from the notion of "interracial justice." While 1 follow him and other Third World intellectuals by centering on indigenousness and people of color and purposefully attempting not to define us in terms of nonWhiteness, 1 believe firmly that interracial justice must include people who critically understand their White racialization and who commit to helping dismantle White Supremacy and other aspects of the contemporary hegemony. Moreover, critical race coalitions should identify, scrutinize, and accept "White" allies when warranted, and we should strategically support their efforts to move communities that will otherwise continue passing as White. For example, critical race coalitions benefit from engaging people who self-identify as Jewish or those from or descended from countries of the former United States of the Soviet Republic and its satellite states, i.e., the former Warsaw Pact. Similarly, successful critical race coalition work must apprehend and accommodate the diverse people whom the contemporary racial formation reifies as "Arab" or "Middle Eastern." On the influential theory of racial formation, see generally Michael OMI \& Howard Winant, Racial Formation in the United STATES: From THE 1960S TO THE I990S (1994). 
new member, who advocates for social justice on one particular "front," law school, of the broad social struggle against subordination. ${ }^{66}$

While many people judge insurgent student activism as unimportant and beyond the proper purview of legal education-often commenting that students should focus on studying because we have our whole lives to devote to social justice-1 believe that the distinctive conditions of U.S. law schools today are ripe for coalescing a new student insurgency. Learning how to critique legal institutions and practicing ethical interventions within the institution of legal education are instances of critical race praxis with potentially radical social effects. In my opinion, one of the insurgency's basic goals is to interrupt law students' subject formation (the psychosocial processes by which people come to understand themselves in relation to others and society) by disrupting what Duncan Kennedy famously called law students' "training in hierarchy" and instead orienting law students toward being social justice advocates for life. ${ }^{67}$ In contrast to law school's obvious purpose of producing new lawyers, relativcly few of whom become public interest, civil rights, or "political" lawyers, insurgent student activism gives law students practice at being "of the people," members of a local community who are learning how to help the community understand and change the roots of its complex and ever

66. My notion of insurgent student activism is related to but does not derive directly from Gerald López's famous book on "rebellious lawyering." See Gerald P. López, Rebellous Lawyering: One Chicano's Vision of Progressive Law Practice (1992). While I have attended lectures that referred to Profesor López's book and heard him speak at the Seventh Annual National Latina/o Law Student Conference, Nuestro Deber: Our Duty to Empower Our Communities (held at the UCLA School of Law, Oct. 10-12, 2003), my notion of the new student insurgency has a distinctive genesis. See also George Lipsirz, American Studies in a Moment of Danger 169-184 (2001) (discussing oppositional movements' need to nurture and maintain "insurgent consciousness"). Lipsitz's essay was originally published bilingually and alongside plates of some of the art works that the essay discusses in George Lipsitz, Not Just another Social Movement: Poster Art and the Moviemento Chicano, in Just Another Poster?: Chicano Graphic Arts in California $71-89$ (Chon A. Noriega ed., 2001). The book was published to complement the Just Another Poster? art exhibit; 1 viewed the exhibit and read Lipsitz's essay in the Fall of 2003, when the exhibit visited my hometown of Sacramento. See Crocker Art Museum, Exhibitions \& Collections, Past Exhibitions, Just Another Poster?, http://www.crockerartmuseum.org/exhibitions/exhib_pages/Just_Another.htm (last visited Oct. 1, 2006). As with Lopez's idea of rebcllious lawyering, Lipsitz's idea of "insurgent consciousness" neither directly caused me to adopt the terms "insurgent activism" or "the new student insurgency," nor did it control my elaborations of these eoncepts. Rather, being a Chicana/o law student at Boalt who read Lipsitz's essay after just having viewed a multitude of vibrant Chicana/o posters in my hometown functioned like a well-planted seed that required additional nurturance to grow. My ideas about insurgent activism and the new student insurgency blossomed in the following seasons, for example, when I was elected to the inaugural executive board of the National Latina/Latino Law Student Association on October 12, 2003, when I was selected as one of the four LatCrit Student Scholars early in 2004, when I attended the Ninth Annual LatCrit Conference later that spring, when I sojourned Chile, Argentina, and South Africa in LatCrit's Critical Global Classroom in the summer of 2004, and finally when I wrote about "insurgent Raza activism" in the aforementioned Berkeley La Raza Law Journal introduction. See infra notes 72-99 and accompanying text.

67. See Duncan Kennedy, Legal Education as Training for Hierarchy, in ThE Politics of Law: A Progressive Critique 38 (David Kairys ed., 1982). 
changing social conditions via legally-informed advocacy. ${ }^{68}$ Insurgent student activism trains law students to critique and contest the current hegemony, that is, to understand the complexity and history of how power and identity sustain the status quo, by providing practice at organizing people around race, gender, sexuality, wealth, age, ableness, etc., to produce socially just change. ${ }^{69}$ Insurgent student activists practice social justice advocacy by learning about and intervening in legal institutions during their legal education, not waiting for some future day, when their social position will have changed from the relative freedom of being a student to the relative constraint of being a legal professional, most likely an attorney.

Without the experience of acting as insurgents, law graduates will likely build careers that remain substantially bounded by ruling ideologies, for example "colorblind constitutionalism." In turn, these ideologies will likely constrain their ability (and desire) to serve communities' ever changing social justice needs. As insurgent student activists, we practice how to be effective social justice advocates right now. As social justice advocates who have trained to resist regnant ideologies, we apprehend the scope and complexity of the current hegemony, understand our relationships to the transnational history of people's creative resistance

68. When 1 use the phrase "of the people," I follow the usage of Latin American liberation philosophers who use it to refer to what is popular and identifies with the subordinated. I adopted this technical usage after attending two conferences at U.C. Berkeley, Latin@s in the World System, 28th Annual Conference of the Political Economy of World System Section of the American Sociological Association (Apr. 22-24, 2004), and Mapping the Decolonial Turn: Post/Trans-Continental Interventions in Philosophy, Theory, and Critique (Apr. 21-23, 2005). Cf. Alicia Gaspar de Alba, Chicano Art: Inside/Outside the Master's House: Cultural Politics and the CARA Exhibit 21 (I998) (adopting Uruguayan artist and philosopher, Luis Camnitzer's critique of the seemingly democratic connotations of the term "mainstream"); cf. infra note 85. See also THE NATIONAL Lawyers' Guild, "Law for the People" Disorientation Handbook: Creating Your Own Progressive Legal Organization 1 (2005-2006), available at http://www.nlg.org/ resources/resources.htm.

69. Hegemony has been described as a "moving equilibrium" that functions ideologically (structurally, unconsciously) to naturalize (make seem given, as if it has to be this way and could never be any other way) contemporary social conditions and maintain the people's consent. See DicK Hebdige, Subculture: The Meaning of Style $15-17$ (1979); The Gramsci Reader: Selected WRITINGS I 9I 6-1935, I 89-200 (David Forgacs ed., 1988) [hereinafter GRAMSCI READER] (Gramsci's writings on hegemony, relations of force, and historical bloc); LISA LOWE, IMMIGRANT ACTs: ON asian American Cultural Politics 68-70, nn.15-18, 86 n.4 (1996) (discussing the several meanings that Gramsci imputed to the concept of hegemony and skillfully using the concept to theorize the meanings of Asian American cultural forms and practices); Kimberlé Williams Crenshaw, Race, Reform, and Retrenchment: Transformation and Legitimation in Antidiscrimination Law, 101 HARV. L. REv. 1331, 1356-69 (1988) (critiquing certain Critical Legal Studies scholars' use of the concept of hegemony by distinguishing between ideological consent and coercive force, and arguing persuasively that the force, not merely consent, features significantly in the subjugation of Black people).

70. See Neil Gotanda, A Critique of "Our Constitution is Color-Blind," 44 STAN. L. Rev. 1 (199I). 
against subordination, and engage the struggle to "abolish....every possibility of oppression and exploitation" daily and until death. ${ }^{71}$

\section{A. Insurgent Student Activism}

I first wrote about insurgent student activism in the Introduction to an issue of the Berkeley La Raza Law Journal ("the Journal"). ${ }^{72}$ There I recorded a "counter-memory" of our recent activities, characterized the contemporary situation at Boalt as "a new chapter of insurgent Raza activism," and concluded with a call for Boalt's Raza alumnae/i to reinstitute sustainable relationships with the Journal and La Raza Law Students Association ("LRLSA"). ${ }^{73}$ I used the Introduction for these purposes for three principal reasons, which all relate to my vision for the new student insurgency.

First, inspired and intrigued by my fragmentary knowledge of the Journal's and LRLSA's history and humbled by my relationship to it, as a member, Articles Editor, Community Service Coordinator, Editor-in-Chief, and Co-Chairperson, I wanted to honor and contribute to la historia de La Raza by recording a slice of our often-unpublished experiences as student

71. On the quote that ends the sentence, see RoBIN D.G. KelleY, Yo' MAMA's Disfunktional!: Fighting the Culture Wars in URban America 78-79, 102 (1997) (describing the slogan on "an old poster announcing the first meeting of the Black Women's United Front to be held in Detroit in January 1975").

72. See Daniel Castro \& Marc-Tizoc González, Introduction, 15:2 Berkeley LA RAZA L.J. (2004) (unpaginated). 1 braid Spanish into my letters' predominant English. For Chicana and Latina explications of the importance of "braiding" for memory and being, see Margaret E. Montoya, Mascaras, Trenzas, y Gredñas: Un/Masking the Self While Un/Braiding Latina Stories and Legal Discourse, 15 Chicano-Latino L. Rev. I (1994); and Berta Esperanza Hernández-Truyol, The LatIndia and Mestizajes; Of Cultures, Conquests, and LatCritical Feminism, 3 J. Gender RACE \& JUST. 63 (1999). "La Raza" or "Raza" refer to concepts developed over the centuries by Mexican and other Latin American intellectuals. See, e.g., Jose Vasconcelos, The Cosmic Race: A bilingual EDIrion (Didier T. Jaén trans., 1979). After the 1960s, these words cannot be simply translated as "the raee" or "race." Rather, Chicanas/os, people living in the United States who transformed their conciencia (awareness, eonsciousness) of their Mexican heritage in light of their experiences of and sacrifices to el Movimiento (the Chicano Youth Power Movement of the 1960s and 1970s) adopted and adapted Vasconeelos's description of "La raza cósmica" (among other ideas) to proclaim a complex new social identity. See generally Carlos Muñoz, Jr., Youth, Identity, Power: The Chicano Movement (1989); F. Arturo Rosales, Chicano!: The History of the Mexican American Civil RIGHTS MOVEMENT (1996). Chicanas/os' new social identity was self-consciously racialized as "Brown" and highlighted cultural, political, and spiritual dimensions of being. See generally IAN F. Haney López, Racism on Trial: The Chicano Fight for Justice 1-3, 152-53, 220-23 (2003); Elizabeth Martínez, De Colores Means All of Us: latina Views for a Multi-Colored Century 1-3, 200 (1998) [hereinafter De Colores].

73. See Castro \& González, supra note 72. On "counter-memory," see GeOrge LiPsitz, Time Passages: Collective Memory and Amercian Popular Culture 213-14, 228-31 (1990). Lipsitz defines counter-memory as "a way of remembering and forgetting that starts with the local, the immediate, and the personal. ... Counter-memory looks to the past for the hidden histories excluded from dominant narratives... [and] focuses on localized experiences with oppression, using them to reframe and refocus dominant narratives purporting to represent universal experience." $I d$. at 213 . 
activists. ${ }^{74}$ I sought to understand and suggest how contemporary student activism related to the origin and evolution of the Journal and LRLSA in order to further our good work by helping retain our organizations' institutional memory.

Second, by characterizing the contemporary situation at Boalt as "a new chapter of insurgent Raza activism," I aspired to contribute to critical race theory and LatCrit theory by articulating how critical theory related to the organized student activism in which I participated. ${ }^{75}$ I desired to draw upon my sociolegal education in critical race theory, LatCrit theory, and other branches of "outsider jurisprudence" and respond to the discourse of critical scholars for the benefit of my compañeras/os at Boalt and Raza law students across the country. ${ }^{76}$ The organized student activism in which I participated and the critical theory I had learned suggested to me that my experience of legal education was part of a decades-long counter-tradition that Boalt's various student organizations and law journals had inherited and evolved from the radical "Power-Identity" movements of the $1960 \mathrm{~s}^{77} \mathrm{I}$

74. Cf. Cho \& Westley, Critical Race, supra note 54, at 1378-80, 1410-12 (arguing persuasively that the critical insights produced by student activism are a form of "subjugated knowledge").

75. Castro \& González, supra note 72. Antonio Gramsci theorized about the roles of intellectuals - those who homogenize and instruct a social group about its economic, political, and social functions-in his famous prison writings. See GramsCi READER 300-11. While law students are not an "essential" social group but rather are an interstitial and ephemeral "class" or social group, Gramsci's theory of the role of the political party is suggestive of the impaet of law students' selforganization into associations and journals that center around a "Power-ldentity." See id. at 310; see infra note 85 . On the synergy between organized student activism and critical race theory, see Cho \& Westley, Critical Race, supra note 54, at 1378-80, 1410-12. See also John Haykawa Török, The Story of "Towards Asian American Jurisprudence" and Its Implications for Latinas/os in American Law Schools, 13 BERKELEY LA RAZA L.J. 271, 290-302 (2002) (critiquing and adapting Cho and Westley's arguments by evaluating them in light of a campaign by Asian Pacific American and South Asian law students at Columbia Law School to diversify the law school's faculty and create the first "Asian American Jurisprudence" course). A similar movement emerged at Boalt in Spring 2003, which I learned about by hearing a pitch to sign the petition in my first year Constitutional Law course. Successful, "Asian Americans and the Law" started in the Spring 2004 semester, and I took it, producing a final paper that investigated and braided together the oft-omitted history of Chinese American and Mexican American litigation against de jure school segregation.

76. On critical race theory, see, e.g., Critical Race Theory: The Key Writings that Formed THE Movement xi-xxxii (Kimberlé Crenshaw et al. eds., 1995) [hereinafter Crenshaw et al., CriticaL RACE TheORY]. On the LatCrit, or Latina \& Latino Critical Theory movement of sociolegal scholarship and praxis, see generally Francisco Valdes, Legal Reform and Social Justice: An Introduction to LatCrit Theory, Praxis and Community, 1 The LATCRIT Monograph Series (2003); and LatCrit: Latina \& Latino Critical Theory, http://personal.law.miami.edu/ fvaldes/latcrit/ (last visited Feb. 28, 2006). On the notion of outsider jurisprudence, see Angela P. Harris, Foreword: The Jurisprudence of Reconstruction, 82 CALIF. L. Rev. 741, 744 n.15 (1994) (noting that Mari Matsuda coined the term).

77. In using the term "Power-Identity," l collect, yet try not to conflate, the several distinct yet related mass movements that contributed to the enrollment of substantial numbers of students "of color" at Boalt in the early 1970s-specifically the Black Power Movement, el Movimiento or the Chicano Youth Power Movement, the Asian American Movement and the American Indian Movement. 1 do not mean to omit the roles played by other movements, but I do not know how they contributed to the enrollment of substantial numbers of students of color during the late 1960s to early 1970 s period 
wanted to record my understanding to persuade current and future students (and our allies amongst attorneys and critical scholars) to rekindle the revolutionary hope of earlier radical movements and to rebuild massive student power con conciencia (with political and spiritual awareness) across universities, colleges, disciplines, and the other social divides that separate us and thereby weaken the people.

Third, 1 hoped to produce a useful tool with which to organize Boalt's present and future Raza alumnae/i, namely a reminder of the Journal's and LRLSA's profound struggle. This struggle is nothing less than la lucha de Latinas/os to obtain a legal education (and its concomitant access to knowledge and power) that might enable us to analyze and intervene in our communities' underlying social conditions in order to serve el pueblo well. ${ }^{78}$ Toward these ends, 1 encouraged Journal members to read the lntroduction and sent copies of it to our alumnae/i, and allied attorneys and scholar-activists, asking them to commit to building sustainable relationships with current students in order to grow Boalt's Raza community and thereby create the conditions for further social justice movement.

\section{B. Tracing the Insurgency's Origins: The Coalition for Diversity}

As 1 understand it, the new student insurgency emerged at Boalt in the dawn of the twenty-first century, after several of the "post-209 years."79 In 2000 , a small group of student activists, primarily women of color, revived and reorganized the former Coalition for a Diverse Faculty \& Student Body ("CDF/SB") into the membership-based Coalition for Diversity. They organized activities to spotlight and decry the exclusion of substantial numbers of people of color from Boalt, but beyond individual actions, the student activists of the Coalition strategized to change the institution.

Understanding the far-reaching social ramifications of this exclusion at Boalt and other public law schools, the Coalition reached out to applicants and admitted students of color, advocated for increased

when affirmative action programs were first implemented at Boalt. See generally GuERrERo, supra note 13, at 7-11, 13-15, 20-23; Berring, supra note 13; Haney López, supra note 13.

78. La lucha refers to the people's perpetual struggle for justice. El pueblo refers to the people communally working together; it also means "the town," connoting the polis.

79. The phrase "post-209 years" refers to the period after the implementation of Proposition 209, the infamous statewide ballot initiative that amended the California Constitution, art. $1, \S 31$, to outlaw state-sponsored affirmative action programs in higher education and contracting. See also supra notes 13-15, 59-62 and accompanying text.

80. Sumi Cho and Robert Westley distinguish membership organizations from coalitions-umbrella organizations that are typically constituted by multiple membership organizations. See Cho \& Westley, Critical Race, supra note 54, at 1383, 1385-90. They also deseribe the organizations antecedent to the Coalition for Diversity. See id. at 1390-1405; Guerrero, supra note 13, at 35-36, 4950, 53-54, 121-35 (discussing activities organized by the Coalition for a Diversified Faculty, the CDF/SB, and related student organizations, like Students Supporting Students); Commentary, supra note 60 , at 1-33 (memorializing students' and one professor's views). 
admissions of applicants of color, elected a student government sympathetic to their interests, and organized teach-ins to educate the next years' classes about the compelling need to increase the number of students of color enrolled at Boalt. In these efforts, the members of the Coalition worked across many dimensions of Power-Identity and struggled to acknowledge and renounce oppressive privileges of gender, race, sexuality, dis/ability, and class. Although they never fully achieved their goals of ending the substantial exclusion of people of color from Boalt or freeing themselves of all subordinating privileges and mentalities, they struggled together daily to realize these goals and had some noteworthy successes.

During this same period, the Supreme Court was deciding the historic University of Michigan affirmative action cases. ${ }^{81}$ As at other U.S. law schools, Grutter v. Bollinger stimulated student activism at Boalt against the national "resegregation" of public education. ${ }^{82}$ Grutter was highly significant to the Coalition's evolution. Student leaders of the Coalition attended the bench trial's opening day at the district court in Detroit, Michigan. ${ }^{83}$ They attended oral arguments at its appeal before the Sixth Circuit in Cincinnati, Ohio. ${ }^{84}$ And, in the Spring of 2003, well into the Coalition's resurgence, the Coalition organized approximately forty Boalt students to visit Washington, D.C., meet with other student activists, and witness oral arguments for Grutter and Gratz before the U.S. Supreme Court. $^{85}$

Through their local struggle, the Coalition's student leaders understood and taught that becoming an effective social justice advocate requires not only critical study of the law in a classroom and dedicated practice in a clinical legal education program, but also critical intervention within the law school itself. And, like classroom and clinical study, learning how to intervene critically within a law school requires practice. In other words, the Coalition's leaders learned to act like insurgents. While many people judge such activism as unimportant or beyond the proper purview of legal education, we in the Coalition realized that advocating effectively for social justice requires continuously critiquing legal

81. These cases were ultimately published as Grutter v. Bollinger, 539 U.S. 306 (2003), aff $g$ 288 F.3d 732 (6th Cir. 2002) and Gratz v. Bollinger, 539 U.S. 244 (2003).

82. See, e.g., Gary Orfield, The Civil Rights Project, Harvard Univ., Schools More Separate: Consequences of a Decade of Resegregation (2001), http://www.civilrightsproject.harvard.edu/research/deseg/separate_schools01.php (documenting resegregation and its effects).

83. See Arrona \& del Peral, supra note 60.

84. See Victor Rodríguez \& Alćgria De La Cruz, Introduction, 13:1 Berkeley La Raza L.J. (2002) (unpaginated); Arrona, De La Cruz \& del Peral, supra note 60; Martínez-Olguín, supra note 60; Muñoz, supra note 60 (recording activist students' reflections on these events).

85. See Victor Rodriguez, Alégria De La Cruz, Alma Lagarda \& Luz C. Valverde, Introduction, 14:1 Berkeley LA RAZA L.J. (2003) (unpaginated) (discussing the visit to D.C. and the press conference organized by the Coalition to mark the students' return and inform the local community of the compelling need to maintain affirmative action programs in higher education). 
institutions, including the institution of legal education, and practicing ethical intervention techniques wherever we're at, including in law school.

\section{Insurgent Subjectivity}

Like you, Rachel and Stephen, I applied for, was admitted, and enrolled at Boalt amidst the Coalition's growth and during the lifespan of the Grutter case. I recall well a student panel presentation at Boalt's Spring 2002 Admitted Students' Day. While simply being present at Boalt felt exciting, when I heard students of diverse social identities proclaim their affiliation with individual Power-Identity organizations like La Raza Law Students Association or Law Students of African Descent and with something called the "Coalition for Diversity," my heart quickened.

Witnessing these strangers (many of whom I would come to love as compañeras/os de la lucha) name a common affiliation across the social groups that so often divide us suggested to me that Boalt's student activists were consciously addressing and perhaps beginning to transcend the problems often attributed to "narrow identity politics" in mainstream discourse. ${ }^{86}$ As the academic year started, I quickly joined LRLSA, the Journal and the Coalition, thereby distinctively shaping my legal education outside of mainstream notions of "merit," "excellence," or "success." 77

Instead of becoming disabled by the profound alienation that I felt from conventional legal pedagogy or succumbing to the meaningless drive of individualist competition that it can engender, participating in student organizations socialized me to identify with the radical countertradition of organized student activism. These organizations helped me critique both the process of legal education and the doctrines themselves. For example, from my first semester at Boalt, while a member of LRLSA, the Journal, and the Coalition, I began interrogating the law's role in the social conditions of Mexican Americans, other Latinas/os and the indigenous people of the Americas. After learning about the absurd notion of the fee simple absolute (infinite ownership of the land), I had to study the repugnant property doctrines of conquest and discovery outside of the course's assigned readings because my professor decided not to cover them, answering when I asked that one must carefully choose a course's first subject so that it will interest the students and be relevant throughout the course. ${ }^{88}$ Through my own studies, 1 came to understand myself $y m i$

86. By "mainstream discourse," 1 follow the usage of Uruguayan artist and philosopher, Luis Camnitzer, who explains that "mainstream" indicates what is popular but identifies with the power elite. See Gaspar de Alba, supra note 68, at 21.

87. For an excellent deconstruction of the mainstream ideologies of bias and merit, see Daria Roithmayr, Deconstructing the Distinction between Bias and Merit, 85 CALIF. L. REv. 1449 (1997); 10 LA RAZA L.J. 363 (1998).

88. She started the course with bailments, continued with adverse possession, and never managed to reach discovery and conquest. 
familia in relation to how U.S. law compelled people of Mexican ancestry to deny our indigenous heritage, denigrate racial Blackness, disassociate ourselves from Asians, and aspire to Whiteness.

During our time at Boalt I grew my hair down to the small of my back and regularly wore it in twin trenzas (braids) ${ }^{89}$ Where some people may have understood my hairstyle as idiosyncratic or discounted it as radical student fashion, I grew my hair long and wore it in twin braids not for fashion but because I felt inspired by criticaI sociolegal scholarship, like that of Profesora Margaret Montoya, and chose to manifest my affiliation with its insights by visibly identifying as Raza. ${ }^{90}$ Additionally, during our years at Boalt, my mother $y$ una tía revealed family stories about their great grandfather, a member of the Kikapu people en México who once helped a young Black man escape slavery by refusing to help the White Texans who came searching for him. ${ }^{91}$ While some may dismiss this knowledge as anecdotal or merely personal, the story profoundly affected me by teaching me about my family's multigenerational commitment to interracial justice and inspired me to transcend my prior vaguely biologistic notions about my "Aztec" ancestry, a belief based as much on the color of my skin, the shape of my nose, and the quality of my hair as on my Mexican heritage and middle name, Tizoc. ${ }^{92}$

89. On the importance of trenzas, see Montoya, supra note 72. See also Paulette M. Caldwell, $A$ Hair Piece: Perspectives on the Intersection of Race and Gender, 1991 DUKE L.J. 365 (deconstructing the legal regulation of African American hairstyles and illuminating the social regulation of African American women via legal reification of invidious and interlocking race and gender stereotypes). For a detailed description of the recovery of indigenous heritage, see Hemández-Truyol, supra note 72.

90. See Montoya, supra note 72 . Also, an entire school of cultural studies has investigated the significance of style, as intentional communication, bricolage, act of revolt, homology, signifying practice, and more. See, e.g., HeBDige, supra note 69, at 100-127.

91. According to my aunt, the Kikapu, typically spelled Kickapoo in English, congregate in several reservations in the United States and two villages in northern México-the ancestral region of my maternal family. For the contact information of the three United States reservations, see American Indian Heritage Foundation, American Indian Tribal Directory, http://www.indians.org/Resource/ FedTribes99/Region5/region5.html (last visited June 3, 2006).

92. Tizoc is a name in the Náhuatl language of the Aztecs. See generally Wikipedia: The Free Encyclopedia, Nahuatl language, http://en.wikipedia.org/wiki/Nahuatl (last visited June 30, 2006). My mother tells me that Tizoc was an emperor of the Aztcc Empire who ruled before its conquest by the Spaniards, whom his priests and generals poisoned to death because he tried to educate the people. While Wikipedia is not usually used in academic works, its articles can provide excellent introductions to specialized knowledge or encyclopcdic overviews of obscure events. See generally Wikipedia: The Free Encyclopedia, Researching with Wikipedia, http://en.wikipedia.org/wiki/WP:RES (last modified Sept. 1, 2006). 1 cite to this resource for three principal reasons. First, Wikipedia manifests an exciting new kind of knowledge because it is a collaborative online project that is free (as in liberty, the GNU Project, and the free software movement). See generally The GNU Operating System - the GNU Project, http://www.gnu.org/ (last modified Sept. 1, 2006); and The Free Software Foundation, http://www.fsf.org/ (last modified Aug. 28, 2006). Second, 1 cite to it sparingly and only to articles that provide substantial bibliographies. Finally, in significant ways, using Wikipedia accords with one of our epistolary's goals - to represent and increase access to forms of subjugated knowledge. See supra note 76 and accompanying text. 
While I had already studied the influential theory of racial formation, which argues convincingly that race is not an immutable biologistic reality but is instead socially constructed, and I was familiar with California's distinctive history of White supremacy, my mother's story, confirmed by her eldest sister, reinforced my interest in understanding how U.S. law contributed to the ongoing racialization, the process by which a social group is constructed as a "race," of Mexican Americans. ${ }^{93}$ For example, prior to law school I knew that the Treaty of Guadalupe Hidalgo ended the U.S.'s invasion of México and resulted in México's cession of the Southwest, and I had read of California's "Greaser Act" and related antivagrancy laws that compelled the indentured servitude of Indians and poor Mexicans. However, prior to Iaw school I had not understood that the U.S. invasion of México occurred in part because México had freed enslaved people decades before the U.S. Civil War. ${ }^{94}$ Viewed in this light, the seizure of Tejas looks like an assertion of slave-holding White male supremacy. Also, without legal education I did not have the legal research skills and lacked the resources to locate an electronically scanned file of the bilingual Treaty of Guadalupe Hidalgo. I did not know that the Federal Record contains many daily bills of Congress's debates on Mexican Americans and had not learned how to access them. These Congressional debates occurred at the onset of the nineteenth century conquest, during squatters' unlawful acquisition of private properties owned by former citizens of México under color of state and fedcral law, and in the twentieth century when Congress authorized the deportation of U.S. citizens racialized as Mexican in the wake of the Great Depression and again in the 1950s ("Operation Wetback"), and also when Congress authorized the infamous Bracero program. ${ }^{95}$

93. On the theory of racial formation, see OMI \& WINANT, supra note 65 . On California's historical White supremacy, see, e.g., Tomás Almaguer, Racial Fault lines: The Historical Origins of White Supremacy in California (1994). On more reeent projects of White supremacy, see, e.g., George Lipsitz, The Possessive Investment in Whiteness (1998).

94. See Almaguer, supra note 93, at 48, 57, 133; Treaty with the Republic of Mexico, Feh. 2, 1848, 9 Stat. 922; cf. In re Rodriguez, 81 F. 337, 350-54 (W.D. Texas 1897) (relying in part on the Treaty of Guadalupe Hidalgo to distinguish Mexicans from "tribal Indians bom and residing within the territory forming a part of the United States" and holding that Mexicans were eligible for U.S. citizenship notwithstanding the contemporary racial prerequisite that limited the right of naturalization to "free white persons"). But see Martha Menchaca, Chicano Indianism, in The Latino/a Condition 387-95 (Richard Delgado \& Jean Stefancic eds., 1998) (detailing the ambiguous legal position of "Mexican-origin people of mestizo descent (Spanish and Indian ancestry)" in the United States). On the historical racial prerequisites to naturalize U.S. citizenship, which remained in force until 1952, see generally, Ian F. Haney López, White by Law: The Legal Construction of Race (1996).

95. See, e.g., George A. Martinez, Legal Indeterminacy, Judicial Discretion and the MexicanAmerican Litigation Experience: 1930-1980, 27 U.C. Davis L. Rev. 555 (1994); Guadalupe T. Luna, En el nombre de Dios Todo-Poderoso: The Treaty of Guadalupe Hidalgo and Narrativos Legales, 5 Sw. J. L. \& Trade AM. 45 (1998); Kevin R. Johnson, International Human Rights Class Actions: New Frontiers for Group Litigation, 2004 MICH. ST. L. REV. 643 (2004); Kristi L. Morgan, Evaluating 
While 1 might have learned how the law contributed to the ongoing racialization of people with Mexican heritage through individual legal research, membership in the Coalition, LRLSA, and the Journal substantially influenced me to take courses like "Race \& American Law," "Asian Americans and the Law," and "Critical Race Theory/Latinos \& the Law." In turn, these classes and the Journal's membership and resources helped me probe deeper into the legal history of in/justice in the United States and provided further opportunities to gain critical knowledge. For example, because 1 had studied outsider jurisprudence and been a leader of LRLSA and the Journal, I attended the National Latina/o Law Student conferences and won election to the inaugural board of the National Latina/Latino Law Student Association (NLLSA). ${ }^{96} \mathrm{I}$ was also selected as one of the 2004 LatCrit "Student Scholars," which enabled me to present at the Ninth Annual LatCrit Conference. ${ }^{97}$ In turn this strengthened my relationships with critical sociolegal scholars, whom I came to view as elder compañeras/os de la lucha rather than distant or isolated figures. The LatCrit Student Scholar Program also provided me with a full scholarship to attend the 2004 Critical Global Classroom ("CGC"), in which I accompanied approximately forty students from law schools across the United States on a six-and-a-half week sojourn to Chile, Argentina, and South Africa, where we critically studied the current sociolegal conditions of our host countries, the histories of the peace and reconciliation movements that followed their brutal dictatorships, and international human rights law in general..$^{98}$

I also came to call myself "Chicana/o" while studying law at Boalt. By serendipity or fate, 1 read Ian F. Haney López's book Racism on Trial: The Chicano Fight for Justice the semester it was published. ${ }^{99}$ In Racism on Trial, Haney López analyzed the criminal prosecutions of Chicano activists in two formative years of el Movimiento, 1968-69 and

Guest Worker Programs in the U.S.: A Comparison of the Bracero Program and President Bush's Proposed Immigration Reform Plan, 15 Berkeley LA RAZA L.J. 125 (2004).

96. On the formation of NLLSA, see Marc-Tizoc González, Dawning of the Sixth Sun: Introducing the National Latina/Latino Law Student Association, THE FourTeENTH AMENDMENT (Nat'l Black Law Students Ass'n, Washington, D.C.), Spring 2004. As NLLSA's first Attorney General-a position that was created because of the national student activism inspired by Grutter $v$. Bollinger, 539 U.S. 306 (2003)-1 worked with Latina/o law students across the country and represented NLLSA at a meeting organized by the Leadership Conference on Civil Rights Education Fund. Helping build and direct NLLSA further reinforced my belief that we live in a moment of resurging student power.

97. See LatCrit Student Scholar Program, http://personal.law.miami.edu/ fvaldes/latcrit/events/ ssp/index.html (last visited June 3, 2006); The LatCrit Student Scholar Program 2006, http://www.law.berkeley.edu/faculty/harrisa/LatCrit.html (last visited June 3, 2006).

98. Describing my experience of the CGC goes beyond the scope of (but profoundly affects) this epistolary. See generally The Critical Global Classroom, http://law.ubalt.edu/cgc/ (last visited Feb. 28, 2006).

99. See HANEY LóPEZ, supra note 72. 
advanced the provocative and powerful theory of "common sense racism" to explain how legal violence and social activism produced the new Chicano social identity, an identity which expressly rejected a White racial identity and instead adopted a new sense of self as racially Brown. ${ }^{100}$ Racism on Trial makes significant theoretical contributions to contemporary understandings of race and racism, and I was deeply pleased to read its contribution to critical race theory and the sociolegal history of Chicanas/os. However, my interest in the book also stemmed from the fact that my mother was a schoolteacher and Chicana activist in Los Angeles during the events the book analyzes.

Without going into the details of my mother's lifelong struggle to nurture la educación de Chicana/o (and all impoverished) youths, I will end this letter by underscoring that engagement in LRLSA, the Journal, and the Coalition helped me recognize and take opportunities to gain radical knowledge of myself, mi familia y el pueblo. Participating in student activism helped me understand our historical relationships to the larger society and gave me practice at advocating effectively and ethically for social justice today.

In this letter I have evoked some of the ways that the new student insurgency helped me critically understand how the law contributed to the racialization of my ancestors and me. Soy Chicanalo hoy dia not because of an imagined (romanticized) connection to a past radical social movement but rather because I understand that I am actually continuing my family's intergenerational contributions to the people's struggle for social justice. ${ }^{101}$ In my next letter I will elaborate why I believe the new student insurgency is so important. Law schools are not only gateways to the legal profession but also politically contested sites of subject formation that shape future legal professionals profoundly. They provide law students

100. See id. at 109-33.

101. Insurgent activism also affected me in other dimensions of Power-ldentity. For example, on the second day of my first semester, some university workers conducted a one-day strike and presented my incoming class with the opportunity to honor or cross the pickct lines. Inspired by the workers and a classmate who said she could not cross a picket line, 1 honored the strike and thereby came to better understand my status as a consumer of formal education along with my relationship to how formal education is produced. As 1 marched, sang, and chanted, alongside the workers and allied students, 1 learned about the possibility of acting in solidarity with people who are differently positioned in society. In the dimensions of gender and sexuality, my peers' protest of the military's recruitment of law students and celebration of the decision in Lawrence v. Texas, 539 U.S. 558 (2003), provided me with opportunities to join their picket lines and share their joy at the decriminalization of homosexuality. This in turn helped me understand my normal complicity in heteropatriarchy and motivated me to act in solidarity with Queerness. Cf. Francisco Valdes, Afterword: Theorizing "OutCrit" Theories: Coalitional Method and Comparative Jurisprudential Experience-RaceCrits, QueerCrits and LatCrits, 53 U. Miamı L. REv. 1265, 1294 n.81 (1999) ('The 'Queer' subject position therefore is not limited to persons or groups who identify or are identified as sexual minority members, though at present a substantial overlap does exist[.]"). 
with lasting lessons about understanding (or denying) their relationships to power, the people, and democracy.

Delighted to share these thoughts with you,

Marc-Tizoc

IV

The Rise and Decline of the Asian American Movement (STEPHEN's SECOND LETTER)

Dear Rachel and Marc-Tizoc,

I'm pleased that you two have tackled my question with earnest and have charted ways in which movements have generated leaders in two different contexts. For my part, I'd like to provide some observations regarding the presence of the Asian American Movement at Boalt. The Asian American Movement was one of the several racial identity or PowerIdentity movements that seized the nation during the late $1960 \mathrm{~s}$ and announced a new identity according to antisubordination principles. Prior to that time, no such term existed that could both name Americans of Asian ancestry and suggest a particular political orientation. Identities were either rooted in the western colonial project (for example, "Oriental") or were fragmented along ethnic lines (for example, Chinese, Filipino, Korean, Japanese).

The paramount and most visible gain of the Asian American movement continues to be the establishment of Asian American Studies departments throughout the country. Today, more students than ever before are taking Asian American Studies courses and identifying with this progressive identity movement. For example, at UCLA, more than 3,000 students take Asian American Studies courses every year. ${ }^{102}$

From the Movement's inception, activists hoped that Asian American Studies departments would provide students with the basic tools necessary to serve and strengthen their communities, to eviscerate the walls separating universities from the people, and enable the two worlds to crosspollinate. In other words, they hoped Asian American Studies would help democratize education. Over the last few years, there has been a flurry of Asian American Movement activity suggesting that the movement is alive and well. Events like the prosecution of Wen Ho Lee, the discrimination suit against Abercrombie \& Fitch, and the federal government's post-9/I 1

102. Glenn Omatsu, Unfinished Tasks in Asian American Studies, Address at UCLA Asian American Studies Departmental Graduation (June 20, 2004), http://www.aasc.ucla.edu/archives/ glennomatsuspeech2004.pdf (last visited Feb. 25, 2006). 
response have rekindled a widespread identification with Asian American racial politics.

But this resurgence only approximates the early movement. Despite the increasing numbers of self-identified Asian Americans on university campuses and the rejuvenated energy with which this generation engages the modern problems of Asian American communities, the words and actions of these activists are increasingly deviating from the original intent of the movement participants. Very specific Movement ideals such as "anti-imperialism" and "serve the people" have given way to more ambiguous and malleable ones like "fairness" and "racial advocacy." Indeed, it is not clear that the term "Asian American" means much more than a neutered reference to persons of Asian descent. Based on both my teaching experiences as a lecturer in Asian American Studies and my time as a student at Boalt, I, like others, believe that Asian American Studies needs to be rejuvenated if the Movement is to achieve its original goals: to secure a measure of racial justice to Asian Americans and to democratize public education. As it stands, the discipline provides its students with an extremely limited set of theories and skills to achieve progressive change. In short, I fear that despite the growing numbers of self-identified Asian Americans they are actually undermining Movement ideals and harming long-term Asian American community interests.

\section{A. The Asian American Movement: A Brief Overview}

The Asian American movement began in 1968 as one part of the Third World Liberation Front, a multiracial coalition of student campus groups at then-San Francisco State College. These student groups united around the fight to establish academic departments devoted exclusively to the study of communities of color. ${ }^{103}$ The typically quiet, working-class campus situated in the flat, western expanse of San Francisco entered the national spotlight as masses of angry students and community members clashed with repressive police forces. As a part of the nation-wide Third World Movement, ${ }^{104}$ students and community members seized San Francisco State College, dismissing classes, setting trash cans on fire, and otherwise disrupting campus operations. They held rallies, some with up to 2,000 demonstrators. In the first two weeks of the strike alone, the police

103. See Omatsu, supra note 10, at 25 .

104. See Karen Umemoto, "On Strike!" San Francisco State College Strike, 1968-69: The Role of Asian American Students, 15:1 Amerasia J. 3, 3-4 (1989) (According to Umemoto, on November 6, 1968, "Student leaders of the San Francisco State College Third World Liberation Front marched with their demands for an education more relevant and accessible to their communities" spccifically calling for "ethnic studies and open admissions under the slogan of self determination... For Asian Americans in particular, this also marked a 'shedding of silence' and an affirmation of identity.") (emphasis added). 
arrested 148 participants. ${ }^{105}$ The end result: activists secured the nation's first department of Ethnic Studies.

Asian American activists were greatly concerned with the Master Plan for Higher Education in California, ${ }^{106}$ a 1960 state statute that is by now quite familiar to Californians. The Master Plan created the three-tiered higher education system, comprised of the University of California (UC), California State College, and junior college systems. Confronted with the changing needs of the economy and a burgeoning student population, the tiered educational system targeted separate student populations and created a more specialized education, under the aegis of a centralized governing board. ${ }^{107}$ Depending on whether students desired to pursue a professional, teacher education, or vocational track, they would enroll in the corresponding institutions. Movement activists didn't see it this way. Rather, they understood the plan as the "restructuring [of] the university based largely upon the priorities of the corporate sector" to the detriment of the cultural and social needs of local communities of color. ${ }^{108}$ In other words, they understood it as subordinating and antidemocratic.

Two items topped the Movement agenda's for reforming the Master Plan. First, movement participants sought to establish an Ethnic Studies curriculum that would provide an "education which would help them retrieve their historical legacy" for the purposes of "contribut[ing] to social change in their communities." 109 Second, participants demanded that the university hire faculty of color; that is, they demanded a hiring policy committed to affirmative action.

But Asian Americans resisted the Master Plan not only to achieve narrow legal reform, but also to launch the more aspirational, antisubordination goals of the Third World Movement. These goals themselves represented a "convergence of struggles... [that] sharply redefined the social norms of our society." 110 The exigencies of a seemingly causeless war in Southeast Asia and the naked reality of racial inequality in the United States led activists to think broadly and in global terms. What is often lost on today's Asian American students, activists, and intellectuals is that Movement consciousness extended beyond borders. Many Movement activists viewed themselves as continuing an international revolutionary struggle; to them, global skirmishes were "antiimperialist wars," and lives were shaped not by civil rights violations, but rather by human rights violations in a state of "internal colonialism." "111

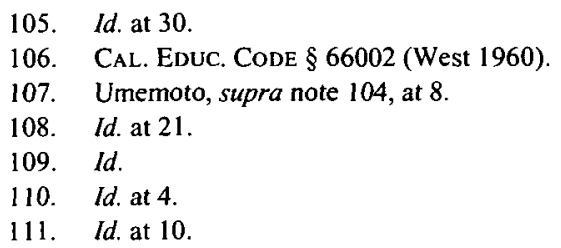


his seminal 1994 essay, The "Four Prisons" and the Movements of Liberation, Asian American historian and activist Glenn Omatsu described the Movement strategy:

[Movement] strategy required activists to develop a broad analysis of the Asian American condition--to uncover the interconnections in seemingly separate events, such as the war in Indochina, corporate redevelopment of Asian American communities, and the exploitation of Asian immigrants in garment shops. In their political analyses, activists linked the day-to-day struggles of Asian Americans to larger events and issues ... or, as summarized in a popular slogan of the period, there was "one struggle, [but] many fronts." $" 112$

One of the distinctive legacies of the Asian American Movement derives from this Third World orientation. The first wave of activists and intellectuals did not proceed in a universe limited to locals of Asian descent, or even progressive allies of color. Rather, the writings from that period clearly suggest a Third World consciousness. References to the Vietnam war, China's cultural revolution, and peasant uprisings in Africa abound in the visual art. The writings of Ho Chi Minh, Mao Zedong, Franz Fanon, Fidel Castro, Malcolm $\mathrm{X}$, and other radical and charismatic intellectuals populated the personal libraries of this generation.

Put another way, the "nation," and the sentiments it is thought to inspire, meant very little to Movement activists. At a time when the "nation" was at war in Southeast Asia, young Movement activists allied themselves with the global communities of color (the Third World), because the nation-state had only served the interests of White elites. Academic departments, affirmative action policies, community organizations - these constituted the very fruits of Movement victories.

\section{B. Asian Americans and the Antidiscrimination Framework}

Thirty-five years after the Movement began, Asian Americans today confront a different reality. The neoconservative (reactionary) movement has seized the nation, and charmed its way into the hearts and minds of many average Americans. The passage of Proposition 209 in California in 1996 eliminated the policy of affirmative action, a key Movement victory.

One of our good friends, who is currently working on the campaign to overturn Proposition 209, explained recently that the greatest challenge he faces is the lack of memory. Students today simply have no recollection of a public university system with racial justice commitments in the form of affirmative action. In fact, according to this friend, affirmative action tends

112. Omatsu, supra note 10 , at 32 . 
to evoke skepticism and distrust in UC students, so effective has the conservative campaign been in stigmatizing the topic. ${ }^{113}$

Consequently, universities have declined as central organizing sites for Asian American activists, and the Movement on this front appears to have stalled. Glenn Omatsu recently observed that they are still many "unfinished tasks facing Asian American Studies and graduates today." For example, "despite the growing number of classes across the nation, the mission of Asian American Studies has narrowed under the pressures to conform to traditional university practices." 115

From what I can tell, both external and internal pressures are responsible for the current, neutered state of the Movement. Externally, Movement activists today are navigating a different racial terrain than those of the past. In the 1960s and 1970s, Asian Americans were considered victims of discrimination; today, they are not. Modern, Leftleaning activists display widespread indifference or resentment to any public call to serve the needs of Asian American communities. On this front, neoconservatives are winning. The model minority narrative has wholly captivated the public's imagination and written Asian Americans off the list of "underrepresented minorities." In one seminar I took as a law student, I proposed writing a final paper addressing the Asian American Movement, to which the professor kindly responded, "Assuming there even is such a thing as an 'Asian American' movement, how are Asian Americans being harmed?" I was particularly indignant because the seminar was explicitly set up to explore the relationship between law and social movements, and had not been offered in the Bay Area-ground-zero of the Movement.

Another reason behind the Movement's relative invisibility derives from the internal orientation of the activists, scholars, and intellectuals themselves. The modern culture of the Movement does not expect Asian Americans to refashion public institutions, such as universities and local government; rather it abides Asian Americans who both indifferently allow Blacks and Latinos to remain excluded from public life, and, at their expense, salvage the remaining public goods, brick by brick.

For example, consider the effect of the model minority narrative, which invites fury, resentment, and above all, a burning desire to disprove

113. Richard Sander's controversial 2004 article calling for the end of affirmative action, and the flurry of responses that followed, though perhaps useful in some respects, likely accorded with and reinforced the now mainstream negative associations surrounding affirmative action. See Daniel E. Ho, Why Affirmative Action Does Not Cause Black Students To Fail the Bar, 114 YALE L.J. 1997 (2005); Richard H. Sander, Mismeasuring the Mismatch: A Response to Ho, 114 YALE L.J. 2005 (2005); Daniel E. Ho, Affirmative Action's Affirmative Actions: A Reply to Sander, 114 Yale L.J. 2011 (2005); Richard H. Sander, A Systemic Analysis of Affirmative Action in American Law Schools, 57 STAN. L. REV. 367 (2004).

114. Omatsu, supra note 102 , at 1 .

115. Id. at 3 . 
this myth even at the expense of other minority groups. In a cogent and thoughtful essay, Playing the Racial Trump Card: Asian Americans in Contemporary U.S. Politics, Claire Jean Kim forcefully argues that Asian American scholars, intellectuals, and students have unwittingly traded in key movement ideals, such as liberation and anti-imperialism, for the seemingly equally beneficial rhetoric of civil rights. Under this regime, the State metes out relief when a "minority deserving remedial aid" incurs an injury at the hands of a "fault-bearing majority."116 This causes a shift in the Asian American subjective framework: a robust and "united Third World struggle against White/Western racism and imperialism" gives way to a more self-centered vision in which Asian Americans, along with Blacks, Latinos, and other "bona fide minority group[s] equivalent in status," jockey for the limited supply of public goods. ${ }^{117}$

Activists today confront a different type of racial exclusion than that faced by our elders; but it does not follow that the principles of the past ought to be abandoned. Movement ideals transmit culture through tradition, and the sense of history it provides is crucial to preventing a total neoconservative triumph.

Take good care,

Stephen

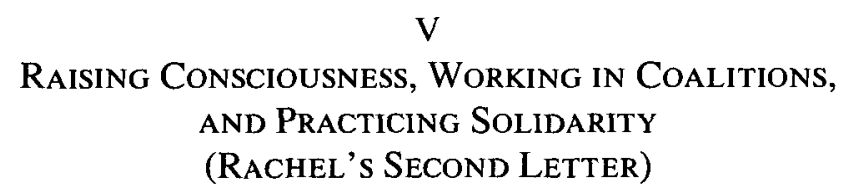

Dear Stephen and Marc-Tizoc,

Entering Boalt in the Fall of 2002, I was faced with the reality that, as an African American law student, I would be among those "in the eye of the affirmative-action storm ever since Proposition 209 banned its use for admissions in California." 18 I had been out of the country for many years, and was unaware that California voters had eliminated affirmative action, that some members of the Black community in California, including Black Boalt alums, had begun a de facto boycott of Boalt, ${ }^{119}$ and that Boalt was

116. Claire Jean Kim, Playing the Racial Trump Card: Asian Americans in Contemporary U.S. Politics, 26:3 Amerasia Journal 35, 42 (2000/2001).

117. Id. at 37 (internal citations omitted). Though many critical race theorists have long lamented the woes and shortcomings of the modern civil rights regime, Kim's article, to my knowledge, is the first to explicitly root the critique in the context of Asian American movement ideals.

118. Bryan A. Tollin, Editor's Note, 7 Afr.-Am. L. \& PoL'y ReP. 107, 107 (2005).

119. During our time at Boalt, there were several times where Black Boalt alums expressed a willingness to meet with current Black Boalt students but would only do so across the street or at some 
on the frontlines of a long-standing battle over the valuation of race in education and in American society as a whole. I, like others before me, ${ }^{120}$ was confronted with unacceptable circumstances that, for me, required an active response.

In this Ietter, I recall some of the crises that framed our timc at Boalt and share examples of consciousness raising, coalitional activism, and increasing solidarity.

At Boalt, a growing "sense of malfunction" led to an audible and visible crisis, ${ }^{121}$ and Boalt students and faculty responded with critical race praxis, social justice activism, and race-plus coalitional efforts. The stories of students' social justice activism at Boalt reveal a simultaneously linear and circular history. The linear history reflects both the order in which events occurred as well as the traditional linear nature of legal analysis. The circular history highlights the repetitive cycles of crisis and activism.

SP-1 and Proposition 209 caused a crisis of access to legal education. ${ }^{122}$ This crisis invokes memories of a crisis twenty-five years earlier, in 1972, when Boalt proposed removing the affirmative-action admissions program for underrepresented minorities only three years after it had been implemented. ${ }^{123}$ Broader social crises also weighed on the minds of Boalt students over an extended period of time. The Spring 2005 town hall on Gender Privilege, sponsored by a broad coalition of Boalt organizations and journals, revealed that women still often felt like outsiders in legal education. This town hall occurred five years after Suzanne Homer (Boalt Class of 1989) and Lois Schwartz (Boalt Class of 1989) published the results of their survey of Boalt students, designed to examine the differences between women and men at the law school. ${ }^{124}$ The issues of underrepresentation of women of color, lesbians, disabled women, and poor women discussed in the Berkeley Women's Law Journal in $1985^{125}$ remain a concern today, eighteen and twenty years after Boalt faculty initially denied tenure to Professor Eleanor Swift and Professor Marjorie Shultz (Boalt Class of 1976), respectively. ${ }^{126}$

other location because they refused to set foot on the campus. Many refused to donate money to the school and this only began to change after Chris Edley, member of the U.S. Commission on Civil Rights, co-founder of Harvard's Civil Rights Project, and former member of both Clinton and Carter White House staff became Boalt's dean in 2004.

120. See, e.g., Gustafson, supra note 60.

121. Cf. KuHN, supra note 17 , at 92 .

122. Arrona \& del Peral, supra note 60 (unpaginated).

123. The program was implemented, in part, in response to 1969 campus-wide Third World Strike that 1 mentioned in my earlier letters, infra. Cho \& Westley, Historicizing, supra note 54, at 33-39.

124. Suzanne Homer \& Lois Schwartz, Admitted but Not Accepted: Outsiders Take an Inside Look at Law School, 5 BeRKELEY Women's L.J. 1 (1989-1990). The survey was administered in March 1988.

125. Editorial Page, 1 Berkeley WOMEN's L.J. (1985) (unpaginated).

126. Cho \& Westley, Historicizing, supra note 54 , at 59 . 
In addition to ongoing concerns associated with gender privilege, the initial defense of affirmative action after Proposition 209 emotionally exhausted many students. Among other things, Proposition 209 resulted in a loss of human capacity to publish journals of color and an insufficient number of students of color to provide other organizations with a racially diverse membership. ${ }^{127}$ In the case of $A L P R$, this diminished workforce "threatened [the] ... [B]lack law journal's ability to participate in the commemoration of Brown." 128 Several journals suffered after the passage of SP-I and Proposition 209, and in the eleven years after the establishment of $A A L J$ and $A L P R, A L P R$ published only seven volumes, $A A L J$ was unable to publish on schedule for several years, and $B L R L J$ struggled to maintain its biannual production schedule. ${ }^{129}$ The editors of $A L P R$ describe the environment in 2004 as plagued by the "loss of institutional memory, self-doubt, a diminished workforce, disillusionment, and fatigue." 130 Many of Boalt's alumni of color withdrew their support from the law school in a de facto boycott, and institutional memory faded in the student-of-color organizations.

At the same time, public expressions of hate increased at Boalt, similar to those that had occurred between 1994 and I998, the years leading up to the passage of Proposition 209. ${ }^{131}$ For example, in 2002, a student-published newsletter ridiculed one professor of color by comparing him to a monkey and questioned the racial background of a mixed-race professor, and student-of-color journals received hate mail during that year's national anthrax-powder terrorism. ${ }^{132}$ This hate mail is reminiscent of the hate mail distributed to first-year law students of color in 1994. ${ }^{133}$ And, similar to the racial hostility expressed in the mid-1990s in connection with a proposed revision to the CLR write-on competition, ${ }^{134}$ racist comments circulated in connection with write-on workshops for underrepresented minority law students. Such attacks generated an unsafe atmosphere and many students sought refuge in student of color journals and organizations.

While at Boalt, I, like you and many others, became very involved in student organizations and coalitions. Those experiences awakened me to

\footnotetext{
127. ALPR Editors in Foreword, supra note 60; Commentary, supra note 60, at 1.

128. ALPR Editors in Foreword, supra note 60, at 130.

129. See Min Lee \& Malcolm Yeung, Editors' Note, 8 AsIan L.J. iv, iv (2001).

130. See Bond \& Pitts, supra note 60.

131. See Gustafson, supra note 60 , at 4 .

132. 1 do not have a copy of this on file as the letters were turned over to the police as evidence. However, in 2003 the Oakland Museum of California produced an art exhibit to document the public response of the East Bay Latino community to the March 2002 hate-mail incident. See Oakland Museum of California, Facing Hate: A Community Responds, at http:/www.museumea.com/ exhibit/exhi_facing.html (last visited August 25, 2006).

133. See id.

134. Delgado, supra note 60 , at 10 .
} 
the similarities between the struggles and goals of many movements, including those with which I had previously identified and those, such as the Asian American Movement, that you, Stephen, discuss in your letters, infra, of which I first became aware during my time as a law student. I believe that many others shared similar experiences, driven in part by the sense of urgency stemming from the awareness of being on the front lines of a crisis. During this time, we both witnessed and actively participated in a resurgence of critical race praxis and social justice praxis at Boalt. As I highlight some of the moments that are of particular importance to me, I am aware that I was not privy to many other acts of activism; this is only a slice of the manifold student activism that took place while we were at Boalt.

Sometimes activism takes the form of refusing to be silenced and continuing to raise your voice to tell your own story. I remember attending the Spring 2005 Town Hall on Gender Privilege, where one of the panelists, a Boalt student, shared her experiences as an Arab American, Palestinian woman. A student leader at UC Berkeley before she enrolled in law school, she often spoke at events, sharing her perspective and the experiences on which it was based. As I reflected that evening while sharing my impressions with you, Marc, at a nearby restaurant after the Town Hall, it was the first time I had ever heard her speak when someone did not immediately stand up to decry her views and perspectives.

I saw her a few days later and told her of my realization, and I expressed my admiration for her perseverance. Tears came to her eyes as she responded that she did not think that anyone had noticed. Then she told me that even this time, she had not been allowed to bear witness to her own life and experiences without someone denying the legitimacy of her perspective. Someone had written to her after the event. At graduation she received an award for her activism, but during her time at Boalt, she did not enjoy the privilege of having her experiences and viewpoint accepted as legitimate in any public forum, including the classroom.

For me, this student's determination is representative of student activism at Boalt: activism requires being present, standing up and being counted, continuing to voice our opinions and perspectives, taking an active part in shaping communities outside the walls of the law school, and contributing to the law school community that we shared by embracing our "margins of divergence." 135 These forms of activism took on particular importance in the post-209 years, as the number of students representing particular racial and ethnic margins of divergence dwindled.

135. Shultz, supra note 60, at 27. Marjorie Shultz defines margins of divergence as the "different issues, persons, rulcs, and justifications [that] spark [one's] interest and empathy in the study of law". Id. at 27 . In practice, margins of divergence lead people to "notice somewhat different things[,] . . ask different (as well as similar) questions[,] and challenge different claims." Id. 
The individual and collective acts of social justice activism at Boalt did not take place in a vacuum. Instead, they took place in the context of group-based and institutionalized efforts to address issues of social justice. Student efforts took many forms including workshops, town halls, intervention in the Grutter case, consciousness raising, and coalition building. In 1997, the Cole Report, ${ }^{136}$ produced by the Boalt administration to assess "the alternatives available to the law school to increase the enrollment of underrepresented minorities," 137 called for the establishment of a Center for Social Justice (CSJ) and the inclusion of social justice courses among first year electives. ${ }^{138} \mathrm{CSJ}$ provided a central institutional structure that helped coordinate social justice theory and practice, and provided a network for students and professors who identified as social justice advocates. ${ }^{139}$ However, the integration of CSJ into the existing network of race-plus coalitional efforts was not seamless. Groups and individuals made conscious and concerted efforts to overcome initial perceptions of CSJ as an organization primarily for White students. ${ }^{140} \mathrm{CSJ}$ is not an umbrella organization but exists in parallel with, and substantially overlaps with, the identity journals and student groups that preceded it. CSJ also played an important role as a point of convergence for professors and practitioners concerned with social justice issues.

The theorizing, scholarship, mentoring, and storytelling of Boalt's social justice-affiliated faculty has had a vital, and as yet unexplored, impact. ${ }^{141}$ Faculty advisors provide critical advice, continuity, and institutional support to student journals and student organizations. Faculty members raised awareness of Boalt's history of social justice activism by preserving institutional memory through storytelling and by willingly engaging in critical race praxis in their advising, teaching, and scholarship. ${ }^{142}$ The courage of professors to speak out against the ban on affirmative action and to share some of the more unsavory aspects of Boalt's past and present encouraged me and other students to recognize and develop our own revolutionary potential. Through faculty storytelling I learned the history of the initial denial of tenure in 1985 and 1987 to two of

136. Report of an Ad Hoc Task Force on Diversity in Admissions, Boalt Hall (Oct. 14, 1997) [hereinafter Cole Report] (written by Associate Dean Robert Cole (chair), Rachel Moran, Edward Tom, and Jan Vetter).

137. GUerRero, supra note 13, at 135 (citing Cole Report, supra note 136).

138. Id. at 135-36.

139. Affiliated professors and practitioners are listed by name on the website. See Univ. of California, Berkeley School of Law - Boalt Hall, Center for Social Justice, Faculty, Practitioners, and other Affiliates, http://www.law.berkeley.edu/centers/csj/faculty/index.html (last visited August 25, 2006).

140. For a discussion of reconstruction, see generally Harris, supra note 76, at 741 .

141. A study of the scholarly contributions of Boalt's professors who have self-identified with the CSJ would provide material for several papers, representing a broad cross-section of legal theory and practices.

142. For more on the value and role of storytelling, see generally Williams, supra note 65 . 
Boalt's widely-respected, White, female professors. Student activism played an integral role in the reversal of those tenure decisions a mere fifteen years ago. ${ }^{143}$ Access to this knowledge allowed us to begin piecing together the institutional memory lost or fragmented in the post-209 era.

Marc, in your letter, infra, you discuss the importance of law school as a site of subject formation that provides many opportunities to understand our relationships to power and the people, and as a place to practice becoming social justice advocates. ${ }^{144}$ Although Boalt had substantially fewer students of color when we attended than it had two decades before, law school nevertheless allowed me to work with other similarly situated Black students in an educational context. Previously, I was almost always the only Black person in my classes, an experience that I believe I share with many Black students at majority White institutions. When I expressed insights stemming from my margins of difference, they were often disregarded, 1 believe because of my lack of 'otherness credibility' due to the lightness of my skin. My classmates and professors viewed my comments as somehow strange, off the mark, or irrelevant. I contrast this with the nodding of heads and murmurs of understanding I received when I made similar remarks behind the closed doors of the $A L P R$ or Law Students of African Descent offices. In this atmosphere of friendship, support, community, and shared goals and experiences, I became involved in critical race praxis and race-plus coalitional efforts.

In 2003, the Law Students of African Descent published a Black History Month booklet ${ }^{145}$ that documented Black History Month events at Boalt through text and photos, and included a 150 year timeline of Black Legal History (that is, legal history that is influenced and defined by the presence of people of African descent in the United States). Although I believed that I was knowledgeable about the intersections between race and law in the United States before enrolling at Boalt, it was only when I was working on the Black History Month booklet that I began to glimpse the depth and pervasiveness of that intersection. By "document[ing] U.S. legal history, as it is influenced by the presence of Black people in [the United States]," the timeline focused on the role of privilege in the United States. ${ }^{146}$ My appreciation of having gained knowledge about U.S. legal history "as it is influenced by the presence of Black people in this country"147 during law school is tempered by disappointment that these

143. These tenure denials have been recorded by many Boalt scholars including GUERRERo, supra note 13, at 49-51, and Cho \& Westley, Historicizing, supra note 54, at 59.

144. Yamamoto (Boalt Class of 1978) also discusses "potential sites of interactions." Yamamoto, Critical Race Praxis, supra note 65 , at 883.

145. This publication is on file with LSAD and is available in the Boalt Law Library.

146. LSAD, supra note 33 , at 5 .

147. Id. 
aspects of legal history are not included as core elements of the law school curriculum.

The booklet also contained a list of all LSAD alumni of whom we were aware, to ensure that collective institutional memory would not be dependent solely on storytelling. ${ }^{148}$ Reconnecting with alumni was an important goal for student-of-color groups. During our time at Boalt, the La Raza Students Association was also reconstructing a list of their alumni. ${ }^{149}$ We had learned the hard way that we could not count on having a storyteller from our community at Boalt, and that we could not rely on a right to access to higher education in California. 1 remember that several of my friends in La Raza Students Association and the Berkeley La Raza Law Journal were also organizing the inaugural Cruz Reynoso Social Justice Fellowship dinner, which allowed them to "create sustainable connections between the Latina/o law students and the Latina/o alumnae/i of Boalt Hall." 150

Student efforts to create collective subjectivities, reconstruct institutional memory, and communities of color at Boalt included storytelling, creating counternarratives, increasing the visibility of populations of color, and identifying with larger domestic and international diasporic communities. ${ }^{151}$ In 2003, LSAD held the first annual Walter A. Gordon Memorial lecture, envisioned as a "vital link to the knowledge and experience of Black Boalt alumni through the continuation of the African tradition of oral history." 152 Notable speakers during our time at Boalt included Judge Thelton Henderson (Boalt Class of I963) and Ed Gordon Jr., historian and son of the Honorable Walter A. Gordon (Boalt Class of 1922), the first Black student to attend Boalt. Although this event was very well attended, it is ironic that year in and year out the most well-attended event sponsored and organized by LSAD is the Soul Food Luncheon. Nonetheless, while sparse attendance was disheartening at best, we were not deterred and strove to achieve a productive and fertile atmosphere for those who attended LSAD events.

148. The list was and is still incomplete. With the help of Professor Richard Buxbaum, former LSAD advisor, we were able to reconstruct an initial, substantial list. However, every so often I discover another name and am reminded how much institutional memory has been lost and still remains to be recovered.

149. The LRLSA website evidences their continuing efforts to revive contact with their alumni. Alumni, La Raza Law Students Association Homepage, http://www.boalt.org/raza/alumni.html (last visited June 29, 2006).

150. Castro \& González, supra note 72 , at ix.

15I. In using the term "collective subjectivities" in these letters, I am not evoking the "collective subjcct", the "person of color" discussed by Angela Harris, supra note 76 , at 755 , but rather the collective subjectivities arising from being Zeitzeugen to converging and overlapping understandings of shared experiences, events, and circumstances.

I52. Id. 
The Welcome Reception held in 2003 by LSAD's sister organization, $A L P R$, proved to be a pivotal event in $A L P R$ 's development. In their opening remarks, the co-editors-in-chief traced the history of $A L P R$ from its 1992 establishment and examined its roots in the Black Law Journal. ${ }^{153}$ The Welcome Reception offered an opportunity to announce that "we are still here" and to claim a right to inhabit Boalt despite resistance, hate mail, and ongoing denial of the need for $A L P R$ 's existence. ${ }^{154}$ The Welcome Reception was vital in strengthening $A L P R$ 's student base. Incoming students cited the Welcome Reception as a key factor in developing their awareness of the challenges the journal had faced due to the resegregation of Boalt, and in 2005, $A L P R$ was able to fill all editorial board positions for the first time in years. Having a full editorial board meant that we could look beyond mere survival towards expanding $A L P R$ 's mandate to respond to changes in the demographic make-up of the U.S. Black population resulting from African and Caribbean immigration. ${ }^{155}$

Another aspect of student activism at Boalt was the fostering of the type of big picture orientation that you, Stephen, discuss, infra, in relation to the Asian American Movement. For example, in 2004, the BLRLJ organized a community forum titled Our Pueblo: Defendiendo Nuestros Derechos/Defending Our Rights which "recognize[d] that community members have as much to teach students as we have to share with them."156 ALPR held a symposium in 2004 entitled The Role of Law \& Policy: Africa, the Caribbean, and the United States, ${ }^{157}$ which "illuminate[d] a powerful rationale for why African Americans should be thoroughly engaged in issues of foreign affairs with [B]lack nations." 158

153. "As part of a consortium, students at the University of California, Berkeley, ... published issues of the [Black Law] Journal with the cooperation of [Boalt] . . and the UCLA School of Law." Dimitri A. Nibbs \& Morris L. Thomas, Preface, 7:2 BlAck L.J. 259, 259 (1981). In 1980, the Black Law Journal remained "the only national publication published at a predominantly white law school by black law students." Id.

154. The Co-Editors-in-Chief answered this question in the first edition of ALPR published in 1994:

In response to those who question the need and/or the propriety of our existence, it is our feeling that without the development of color-conscious joumals such as ours-fora where students and scholars find a ... place to analyze issues affecting people of color-we will never solve the problems affecting African-American communities.

Mario L. Barnes \& Angela N. Watkins, Editors' Note, 1:1 Afr.-AM. L. \& Pol'y REP. (1994).

155. See Tollin, supra note 118 , at 109 .

156. Symposium, Berkeley La Raza Law Journal Homepage, http://www.boalt.org/LRLJ/ our_pueblo.html (last visited Aug. 27, 2006).

157. The suggestion to hold a symposium on this topic initially met with resistance. When the idea for the symposium was first suggested by the Symposium Editor, members of $A L P R$ 's editorial board questioned the relevance of a symposium on international issues when it seemed that there were so many national issues that had equal or greater need to be addressed in such a forum. It was only after many challenges and discussions that the rest of the editorial board became convinced that international struggles for human rights and anti-subordination were important both for our struggles and for the local and national struggles.

158. Tollin, supra note 118 , at 107-08. 
Also during our time at Boalt, the UC Berkeley Black Graduate Student Association (BGSA) was revived. Black law students took an active role in the revival of the BGSA, which was important since, as you discuss in your second letter, infra, Marc, law schools enroll a much larger number of students than other graduate programs. The East Bay Community Law Center clinic, ${ }^{159}$ law school institutions such as CSJ, and academic conferences such as the annual LatCrit and Law \& Society Association conferences also offered alternative sites for the exploration and development of critical race praxis and social justice praxis.

The growth of collective student subjectivity during our time at Boalt fostered support for symposia that transcended traditional boundaries. The Berkeley La Raza Law Journal and the Berkeley Journal of Employment and Labor Law jointly organized a symposium in April 2005 titled Making Movement: Communities of Color and New Models of Organizing Labor, to address "contemporary struggles to organize labor while fundamentally critiquing conventional notions of citizenship." 160 The goals of the Berkeley Journal of Gender, Law \& Justice (a continuation of the Berkeley Women's Law Journal), 2005 symposium titled Gender and Migration, included "identify[ing] avenues for resistance, and discover[ing] means through which migrant and immigrant women might be empowered through the process of migration." 161

Coalitional activism helped us share our knowledge and better undcrstand the perspectives and needs of our peers, peer organizations, and the communities they belong to and represent. In the years following Proposition 209, coalitions were integral to the survival and revival of student activism, including the publication of specialized journals focusing on issues of race and gender. In 2003, a coalition of twenty-eight Boalt student organizations and journals, the Equal Justice Society, and the Hastings Journal of Race and Poverty Law held a conference titled Coalitions at the Crossroads: Access to Justice. ${ }^{162}$ According to the

159. It was during our time at Boalt that the first Black law student participated in the Death Penalty Clinic.

I60. Berkeley La Raza Law Journal Homepage, http://www.boalt.org/LRLJ/symposium.htmI (Iast visited May I, 2005).

I61. Symposia, Berkeley Journal of Gender, Law \& Justice Homepage, http:/www.boalt.org/ bwlj/symposia.htm (last visited May 1, 2005).

162. The Boalt student journals and organizations planning the symposium were: AfricanAmerican Law \& Policy Report; Asian American Law Journal; Asian Pacific American Law Students Association; Boalt Disability Law Society; Boalt Hall Women's Association; Berkeley Journal of Employment and Labor Law; Berkeley Journal of International Law; Berkeley La Raza Law Journal; Berkeley Law Foundation; Berkeley Women's Law Journal; California Criminal Law Review; California Law Review; Center for Social Justice; Coalition for Diversity; Ecology Law Quarterly; Environmental Law Society; Health Care Law Society; La Raza Law Students Association; Law Students of African Descent; Lesbian, Gay, Bisexual, Transgender Caucus; Native American Law Students Association; Prisoners Action Coalition; Stop Domestic Violence; Sports and Entertainment Law Society; South Asian Law Students Association; and Youth Education Law Society. More 
mission statement for the symposium, "[c]oalitions represent the best hope for the successful marshaling of resources and group interests. Where legal issues cross boundaries of geography and identity, problem-solving in our diverse society requires the creation of coalitions." 163 The conference included panels on Civil Rights, Human Rights, and Law in the 21 st Century; Race, Class, and the Environment; Constructing Nations; Community Response to Crisis: Criminalizing Reproductive Rights; Desegregating Higher Education; and Caught in the System, which addressed the ways that systems of power and control regulate members of particular communities. Many of the panelists were current or former Boalt students.

Two years later, in another broad coalition, CSJ, identity journals, and other student associations cosponsored a series of town halls on class, race, gender, and sexual orientation in 2005 and $2006 .{ }^{164}$ In a role reversal that reflected a willingness to challenge traditional power relationships, student panelists presented the theory and professors discussed their personal experiences. These events offered a space in which difficult conversations about privilege could be expressed and discussed among the wider Boalt community. ${ }^{165}$ In a larger forum, challenging widely held assumptions proved to be highly difficult, and these discussions were a first step toward moving beyond the basic identification of issues to achieving intergroup healing and forging lasting alliances. ${ }^{166}$

The quantity and quality of social justice activism within and beyond the walls of the law school over a short period of time gave students many opportunities to critically engage with the issues facing different communities and hear the voices of those communities firsthand. Identitybased student organizations at Boalt collectively moved beyond the individual concerns of their communities and began focusing on the

information is available on the conference website http://www.boalt.org/coalitions/ (last visited May 1, 2005).

163. Mission Statement, Coalitions at the Crossroads: Access to Justice Homepage, bttp://www.boalt.org/coalitions/mission.html (last visited Aug. 25, 2006).

164. See Center for Social Justice, Review of Spring 2005 Events, Boalt Hall CEnTER for SOCIAl Justice NewsletTER, Fall 2005, at 6; http://www.law.berkeley.edu/centers/csj/newsletter/ Fall05.pdf\#search $=\% 22$ Center $\% 20$ for $\% 20$ Social $\% 20$ Justice $\% 2$ C $\% 20$ Review $\% 20$ of $\% 20$ Spring $\% 20200$ $5 \% 20$ Events\%2C\%20BOALT\%20HALL\%20CENTER\%20FOR\%20SOCIAL\%20JUSTICE\%20NEW SLETTER $\% 22$.

165. For example, at the town hall on race privilege, "[o]ne student of color expressed frustration about the burden of always baving to educate [W] hite people about race privilege." NEws, National Lawyer's Guild at 7 (Mar. 2005), http://www.nlgsf.org/ Newsletter/PDF/2005/March_2005.pdf\#search=\%22boalt $\% 20$ town $\% 20$ hall\%20on\%20race $\% 20$ privileg $\mathrm{e} \% 22$.

166. Julie Su and Eric Yamamoto argue that "among coalition partners, intergroup healing and reconciliation are sometimes a necessary first step to and an always ongoing process in, forging lasting alliances." Julie A. Su \& Eric K. Yamamoto, Critical Coalitions: Theory and Praxis, in Crossroads, supra note 54 , at 381 . 
overlapping needs of historically subjugated communities. Students began to reclaim our collective subjectivity and exercise our voices by managing organizations and journals. We experimented with and strengthened our skills and institutional memory while engaging with one another and the larger communities of Boalt, UC Berkeley, and the surrounding area. As you both discussed earlier, infra, experiences of student activists at law school often go unrecorded; access to this knowledge is critical to the sustainability and ultimate success of social justice praxis.

Sincerely,

Rachel

VI

Multidimensional Social Justice Advocates in the Dawning

TWENTY-FIRST CENTURY

(MARC-Tizoc's SECOND LETTER)

Querida/o Rachel y Stephen,

Thank you for your beautiful letters. Rachel, thank you for informing us of Boalt's long and cyclical history of social justicc activism and highlighting its racial history. The Black History Month Booklet and other Black History Month events organized by LSAD affected me greatly. Stephen, thank you for reminding us of the Third World Movement's goal of democratizing education for international anti-subordination purposes and sharing your thoughts on how the neoconservative movement has partially countered the radical potential of the Asian American movement. I remember many long-night meetings of the Coalition in the APALSA office and recall the deep delight I felt when one of our good friends found some Movement-era photographs in it. While APALSA and LRLSA both "suffered" at times from members who felt that socializing was opposed to the organizations' founding and contemporary dedication to social justice student activism, seeing those old photographs amidst our friends and allies suggested to me the vitality of the Asian American movement at Boalt. Indeed, the degree to which our Power-Identity organizations are contested shows to me their importance in coalescing the new student insurgency.

\section{A. Law Schools as Politically Contested Sites of Subject Formation}

The twenty-four year old Federalist Society for Law and Public Policy Studies works toward "reordering priorities within the legal system to place a premium on individual liberty, traditional values, and the rule of law. It also requires restoring the recognition of the importance of these norms 
among lawyers, judges, and law professors." 167 While such a political project neither begins nor ends at law school, formal legal education is one of the places where this struggle must occur. Indeed, the recent confirmations of Chief Justice John G. Roberts, Jr. and Associate Justice Samuel A. Alito, Jr. to the U.S. Supreme Court have made clear the importance of shaping the minds of future generations of legal elites.

However, law schools are not merely gateways to power. Beyond the significant career opportunities that students may develop at a school like Boalt, law schools are politically contested sites of subject formation. The years that law students spend in the temporary communities formed by law schools not only facilitate the development of career opportunities. Those years also significantly shape students' future lives, such as their basic ideas about justice and their personal sense of responsibility to protest injustice and help build a just society. ${ }^{168}$ While law schools do not inevitably control people's destinies, they function like crucibles into which individual law students are dropped, fusing doctrinal knowledge and ideological presumptions for three years with students' experiences prior to their enrollment. To evoke Patricia Williams' famous metaphor, law schools are alchemical; they substantially transform people, initiating us into the fundamental mysteries of how society regulates power and wealth. ${ }^{169}$

Because law schools are politically contested sites of subject formation, they are especially important to coalescing the new student insurgency and building student power more generally. Despite the vicissitudes of the enrollment of students of color and others who identify outside the mainstream, law schools enroll substantially larger numbers of students than other graduate programs. Whereas many Ph.D. programs enroll less than ten total students a year, law schools like Boalt regularly enroll several hundred people a year. Additionally, the continued presence of the organizational descendants of the Power-Identity movements (like the Coalition, APALSA, LRLSA, LSAD and Boalt's Power-Identity journals) makes law schools crucial sites for coalescing broad student power.

However, law schools also have distinctive features that may retard this coalescence. The common three-year program pushes students out relatively quickly, sapping collective memory and thereby weakening organizational power. This is why activist law students need allies amongst other programs and disciplines and across the under/graduate divide.

167. The Federalist Society for Law and Public Policy Studies, Our Purpose, http://www.fedsoc.org/ourpurpose.htm/ (last visited Feb. 28, 2006).

168. See generally Francisco Valdes, Insisting on Critical Theory in Legal Education: Making Do While Making Waves, 12 Berkeley La RAZA L.J. 137 (2001).

169. See generally Patricla J. Williams, The Alchemy of RaCe and Rights (1991). 
Reciprocally, other student populations can benefit from our distinctive focus on law, our organizations' histories, and our numbers.

I developed my understanding of law schools' distinctive possibilities for building student power by attending the "Raza Caucus" meetings organized by Latina/o undergraduate students at UC Berkeley. At those meetings, I experienced solidarity with activist undergraduate Raza across departments and the under/graduate divide. In turn, we all benefited from glimpsing intergenerational solidarity: not only was I a law student, but I was obviously older than the undergraduates, who could not remember the last time a Raza law student had attended their meetings. In turn my experience of solidarity across departments and the under/graduate divide motivated me to help resuscitate the dormant Latino Graduate Student Association ("LGSA"). As a student leader at Boalt, I had experience organizing Latina/o graduate students that many UC Berkeley Latina/o graduate students lacked.

Organizing LGSA, I came to believe that Boalt's critical race coalitions could transcend the law school and contribute to building massive student power, not to hearken back to earlier eras, but instead to engage contemporary social struggles, qua students. For example, the current controversy over U.S. immigration policy could benefit from the large-scale engagement of students, and law students could serve a role in helping other students learn about immigration law and policy. Additionally, some of our law student friends joined undergraduate students and established civil rights organizations to defeat Proposition 54, the California initiative that would have banned the state from collecting racial information. ${ }^{.70}$

I believe that these are examples of the radical potential of the new student insurgency and think that the possibility of building massive student power is a worthwhile endeavor for our internally divided society. However, I expect that some people may disagree with the entire notion that law schools are sites of subjcct formation, despite the transparency of the Federalist Society political project and those of its funders and allied neoconservative organizations. ${ }^{171}$ Therefore, I want to briefly discuss how the U.S. Supreme Court impliedly affirmed law schools' importance as sites of subject formation in Grutter.

170. See League of Women Voters, Proposition 54: Classification by Race, Ethnicity, Color, or National Origin, http://smartvoter.org/2003/10/07/ca/state/prop/54/ (last visited Sept. 1, 2006).

17I. See Alan Jones, Connecting the Dots, Inside Higher Ed (Jun. 16, 2006), http://insidehighered.com/views/2006/06/16/jones (analyzing the funding of the Federalist Society and othcr neoconservative organizations). 


\section{B. Social Diversity and Subject Formation}

Writing for the majority in Grutter, Justice O'Connor held that "student body diversity is a compelling state interest that can justify the use of race in university admissions" and found that the University of Michigan School of Law's admissions program was sufficiently narrowly tailored to withstand strict scrutiny. ${ }^{172}$ The Court further found "that the Law School sufficiently considered workable race-neutral alternatives" and that the plan did "not unduly harm nonminority applicants" because of "its individualized inquiry into the possible diversity contributions of all [its] applicants." 173

The Court's holding incorporated deference to the law school's "educational judgment that such diversity is essential to its educational mission," and Justice O'Connor based this deference on Justice Powell's recognition in Bakke that "educational autonomy" is grounded in the First Amendment. ${ }^{174}$ Justice O'Connor explained that student body diversity is a compelling state interest, because diversity produces a number of societal benefits: it can improve learning outcomes, increase professional preparation for the global marketplace, stimulate effective civic engagement by members of all social groups, support the apparent legitimacy of the nation's leaders, maintain national security effectiveness, and diminish invidious stereotypes. ${ }^{175}$ While Justice O'Connor's opinion does not mention subject formation, it implies the concept by linking student body diversity to a robust set of social benefits. A socially diverse student body does not automatically produce such benefits. Rather, experiencing social diversity during law school produces law graduates (subjects), who have effectively been trained to produce those benefits over the course of their careers.

Note that O'Connor's opinion differs radically from the views expresscd by the dissents of Associate Justices Thomas and Scalia. For example, Justice Thomas's dissent redefined the law school's asserted compelling interest in social diversity by calling it "an 'aesthetic."'176 From his dissent, Justice Thomas appears to believe that aesthetics are superficial or epiphenomenal, which is also how he appears to understand race. ${ }^{177}$ However, aesthetics are not merely superficial; indeed aesthetics constitute a branch of philosophy, and what people find beautiful is profoundly and complexly connected to the personal and cultural meanings we ascribe to appearances, whether they are the color of a person's skin, the shape of

172. Grutter v. Bollinger, 539 U.S. 306, 325, 334 (2003).

173. Id. at $340-41$.

174. Id. at 328-30; see also Regents of Univ. of Cal. v. Bakke, 438 U.S. 265, 312, 319 n.53 (1978) (opinion of Powell, J.).

175. See Grutter, 539 U.S. at 328-31.

176. Id. at $349,355-57$.

177. See id. at 355 n.3 (referring to "the color of one's skin"). 
her/his body, the quality of her/his hair, the sound of a violin concerto or steel drums, the lucidity of a forest lake or the bustle of a stock exchange. Moreover, as critical race theorists have explained, the social construction of race includes but transcends mere skin color. ${ }^{178}$

Again, while Justice Thomas never mentions social formation, the concept is implied in his insistence that the law school's asserted compelling interest amounted only to the desire for a fashionable aesthetic. Beyond the intimate relationships that people develop with their colleagues at law school, the "aesthetic" that one gets used to during law school likely influences the kind of people one expects to see as a legal professional. Note that I do not suggest that law schools ineluctably shape law graduates' desires or sense of beauty, but I do believe that law schools substantially influence the kind of people students are used to seeing as colleagues, mentors, and menials. To the degree that law students' subject formation has been disrupted from the conventional "training in hierarchy," law students will be less likely to presume that a person who "looks Mexican" is a janitor or that a Black man is a criminal instead of being potential attorneys, judges, law professors, etc.

Justice Scalia also dismissed the educational benefit sought by the University of Michigan's affirmative action program, asserting that "it is a lesson of life rather than law-essentially the same lesson taught to (or rather learned by, for it cannot be 'taught' in the usual sense) people three feet shorter and twenty years younger than the full-grown adults at the University of Michigan Law School, in institutions ranging from Boy Scout troops to public-school kindergartens." 179 Again, while Justice Scalia doesn't mention social formation, his dissent comes closest to discussing the concept. He likens the educational benefits of student body diversity to a "life lesson" of childhood, in other words to early socialization or acculturation. However, his use of the Boy Scouts as an example is strikingly gendered in a male-dominant way that presumes or implies a normative heterosexual standard. It is gendered in a male-dominant way because only boys can join the Boy Scouts, and his dissent did not mention the Girl Scouts or some other distinctively female organization. While some people might interpret Justice Scalia's comment to incorporate girls, the implied heterosexual supremacy of Justice Scalia's comment makes this interpretation untenable. Three years earlier, in Boy Scouts of America v. Dale, Justice Scalia joined the majority that overruled the New Jersey

178. See, e.g., Tanya Katerí Hernández, Multiracial Matrix: The Role of Race Ideology in the Enforcement of Antidiscrimination Laws, A United States-Latin America Comparison, 87 CORNELL L. Rev. 1093 (2002); Trina Jones, Shades of Brown: The Law of Skin Color, 49 DukE L.J. 1487 (2000); lan F. Haney López, The Social Construction of Race: Some Observations on Illusion, Fabrication, and Choice, 29 HARV. C.R.-C.L. L. REv. 1, 3 n.5 (1994); Gotanda, supra note 71; OMI \& WINANT, supra note 65; Caldwell, supra note 89.

179. Grutter, 539 U.S. at 347 (Scalia, J., concurring in part and dissenting in part). 
Supreme Court and held that the Boy Scouts had a First Amendment right to bar homosexual men from serving as troop leaders. ${ }^{180}$

Thus, Justice Scalia's dissent asserted that law schools are not the proper places to learn "a lesson of life rather than law" but seems to have based this assertion on a presumption of a male-dominant heterosexual standard. Justice Scalia's dissent thus provides a useful example of the subject formation that law schools engender and also suggests the importance of coalescing the new student insurgency for people who are interested in contributing to a society that does not invidiously discriminate between people because of their sexuality.

Justice Scalia's dissent also suggested targets for future litigation, naming "those universities that talk the talk of multiculturalism and racial diversity in the courts but walk the walk of tribalism and racial segregation on their campuscs - through minority-only student organizations, separate minority housing opportunities, separate minority student centers, even separate minority-only graduation ceremonies." ${ }^{\prime 18} \mathrm{He}$ appears to be ignorant of the fact that student organizations that center on people of color or other outsider Power-Identities tend not to exclude anyone on an essentialist basis. That is what mainstream society has done to us. Rather, people who unreflexively identify with a dominant social identity tend to presume they are unwelcome and therefore usually don't take the opportunity to join us, or they socialize with us but then refuse to seriously engage us in our organizations. At Boalt, for example, both LRLSA and the Journal featured significant numbers of people who did not identify as Raza but who felt solidarity with us and therefore participated in our organizations. Also, significant numbers of students who identified as Latina/o participated in organizations at Boalt that do not center on Latinas/os. While misunderstandings sometimes occurred, these organizations and others like them provide social spaces in which to discuss our differences and create interracial and other forms of social justice by building common understandings. In turn, law students who experience solidarity across multiple dimensions of power and identity will develop skills that are highly useful for their lifelong work as social justice advocates.

\section{Multidimensional Solidarity}

U.S. law schools with active student organizations and journals that have inherited the legacy of the Power-Identity movements provide students with many opportunities to develop and practice their understanding of the law outside of mainstream ideologies. While everyone experiences law school individually, activist student organizations can

180. Boy Scouts of America v. Dale, 530 U.S. 640 (2000).

181. Grutter, 539 U.S. at 349. 
engender a scnse of solidarity that is not premised on an unreflective identification with the power elite or on essentialist, usually biologistic, notions about racial identity, but is instead based on a critically conscious and anti-essentialist dedication to social justice.

At Boalt, since Admitted Students Day, the existence of LRLSA and the Journal intrigued and influenced me. Although I grew up Mexican American in an extended familia of cousins in Sacramento, California, worked as a mental health counselor in and around the predominantly Latina/o community of Pomona, California, for two years, and studied Chicana/o youth, gangs, and graffiti while earning my Master's degree at San Francisco State University before enrolling at Boalt, I had never heard the terms "Raza" or "La Raza" used as regularly as when I studied law at Boalt. While I had previously imagined the Chicana/o Power Movement and other Power-Identity movements as primarily historical, Boalt and UC Berkeley taught me of their enduring vitality.

I felt particularly fascinated by our attempts to help each other flourish at Boalt by organizing ourselves around an internally complex, yet not biologistically-based, Raza identity. ${ }^{182}$ While neither LRLSA, nor the Journal ever completely escaped essentialist notions of race or the other dimensions of Power-Identity, e.g., gender, sexuality, ableness, age, wealth, etc., we struggled together to acknowledge and resist these notions. For example, we challenged the machismo from which earlier instances of el Movimiento suffered. ${ }^{183}$ While las mujeres were often unduly burdened with leading these struggles, and a significant proportion of us seemingly remained homophobic or heterosexist, both the Journal and LRLSA provided multiple opportunities to begin transcending oppressive ways of being.

I mention some of these experiences because while it was important to engage in and deepen our identification como Raza, this identification was necessary, not sufficient, to realizing our potential to become the social justice advocates whom I believe our communities need in the twenty-first century, people who are aware of the complexity of the current hegemony,

182. For an influential and sophisticated account of the "what black women can bring to feminist theory to help us move beyond essentialism and toward multiple consciousness as feminist and jurisprudential method," see Angela P. Harris, Race and Essentialism in Feminist Legal Theory, 42 Stan. L. Rev. 581, 608-16 (1990). Profesora Harris's influential critique also helps one imagine how to transcend essentialism in organized student activism. See also Harris, supra note 76, at 759-65 (describing the "politics of difference" by discussing the tensions between "resistance culture," critical race theory, and the problem of the subject)

183. Machismo denotes male chauvinism, which is based on presumptions about the morality of heterosexuality and homophobia. For discussions of machismo en el Movimiento, see, e.g., DE Colores, supra note 72, at 172-81; Rosales, supra note 72, at 258-60; and Ramon A. Gutierrez, Community, Patriarchy, and Individualism: The Politics of Chicano History and the Dream of Equality, 45 AMERICAN QUARTERLY 44 (1993). 
knowledgeable of its transnational history of subordination, and willing to join the struggle against injustice across all borders.

To understand the multiple dimensions of the current hegemony, i.e., that the status quo relies on dividing people by race, gender, sexuality, etc., to privilege some by subordinating many others, and learn about the people's history of creative resistance to subordination, it is necessary to build community across many social divides. At Boalt, the new student insurgency arose first amongst the people who constituted the Coalition for Diversity, people who struggled together across our diverse PowerIdentities and chose to act in radical solidarity como ser humanos (as human beings). While joining LRLSA and the Journal catalyzed my personal transformation into a multidimensional social justice advocate, I was only able to achieve my "action potential"184 after joining the Coalition-attending our frequent, lengthy Strategy Committee meetings, discussing seriously with others how to protest injustices and build social justice, and collaborating on our events and actions. By regularly engaging the Coalition's other leaders in those late night meetings, we practiced solidarity across multiple dimensions of Power-Identity, developed our abilities to listen carefully, sought to dismantle our presumptions, and learned to challenge each other ethically and with compassion-all characteristics necessary to advocate well for social justice. ${ }^{185}$

Participating in the Coalition also helped me practice interracial solidarity at Boalt. For example, I distinctly recall attending the then- $A L P R$ journal release celebration in our first year at Boalt. As I sat and listened to the speaker, noticed how few of us were in the room, reviewed the thinness of past issues, and reflected on the struggle of "my" Journal to maintain regular production, I felt my understanding of self and community changing. While 1 focused my energies on LRLSA and the Journal, I didn't think of Black or Asian American students as Other but rather as actual or potential compañeras/os, partners in the struggle for interracial justice at Boalt and beyond. Similarly, as I mentioned in my previous letter, being a student activist changed my understanding of sexuality, Queerness, feminism, and indigenousness. While we should not conflate our social differences and must resist facile notions of celebrating our

184. I explain my usage of action potential below. In neuroscience, action potential refers to the process whereby synapses (the spaces between neurons) "fire." For an electrical charge to traverse the synapses between neurons, several actions must occur that involve a reversal of electrical potential and often require a catalyst, a substance that increases the rate of a reaction without being consumed in that process. See generally Wikipedia: The Free Encyclopedia, Action Potential, http://en.wikipedia.org/wiki/Action_potential (last visited June 29, 2006).

185. For example, my clinical legal education program at the East Bay Community Law Center required me to liaise between the legal team of a high impact affordable housing case in Oakland's Chinatown and the community support committee. The skills that I developcd as an activist student substantially improved my ability to work effectively with the community leaders, helping me to be a good ally while fulfilling my professional responsibilities. 
differences, people can act in sincere solidarity, and over time these experiences build the common understandings that enable us to produce social justice.

For example, in my previous letter, I recounted some of the reasons I now call myself Chicana/o. In addition to a personal sense of indigenousness, I now understand identifying as "of color" in terms of what Lani Guinier and Gerald Torres called "political blackness," that race is neither primarily about skin color, nor merely about assigning blame, but rather "a political framework that cultivates and inspires action directly."186 Similarly, noted cultural critic Stuart Hall identified a similar point in his examination of Blackness in Britain. ${ }^{187}$ Discussing a shift into a new phase of the historical moment of post-war Britain, Hall reflects on "the moment when the term 'black' was coined as a way of referencing the common experience of racism and marginalization in Britain and came to provide the organizing category of a new politics of resistance, among groups and communities, with, in fact, very different histories, traditions, and ethnic identities." 188

Before law school, I studied Hall and other cultural theorists at San Francisco State University in a project to explore and represent the youth practice of graffiti. This research helped me begin to understand the performative aspects of race. At the same time, living in the San Francisco Bay Area, I witnessed the social diversity of a cosmopolitan city. In turn, these studies and life experiences primed my potential to act in solidarity with people with different histories, traditions, and identities, and prepared me to practice interracial and other forms of solidarity at Boalt. While my solidarity may have seemed reflexive to others, i.e., "Yeah Tizoc, you know he's down," the fact that I came to practice solidarity regularly with people organized as LSAD, $A L P R$, the $A A L J$, and the Native American Law Students Association or the Queer Caucus, was relatively new in my life. My previous activism, which focused on antiracism, feminism, and environmentalism, was bounded by colorblindness and other ideologies that framed my experiences of solidarity as individualist choices rather than enabling me to understand the interconnections of the multiple dimensions of solidarity, privilege, subordination, and power.

Starting with the $A L P R$ Welcome Reception and first annual Walter A. Gordon Memorial lecture, I attended almost all of that year's Black History Month events, especially the film series. Again and again I noted how few of us were in the room and contrasted this fact with how enriching

186. Lani Guinier \& Gerald Torres, Excerpt from The Miner's Canary: Enlisting Race, Resisting Power, Transforming Democracy, 27 N.Y.U. Rev. OF L. \& Soc. Change 1, 3 (2001-02) (discussing why they ultimately replaced the term "political blackness" with the phrase "the political race project");

187. Stuart Hall, New Ethnicities, in Critical Dialogues in Cultural Studies (David Morley \& Kuan-Hsing Chen, eds. 1996).

188. Id. at 441 . 
the events' pedagogy felt. While those who ascribe to the point of view expressed by Justice Scalia in Grutter may dismiss the importance of such experiences or suggest that they belong outside of the law school, such a viewpoint suggests an exclusionary intent that underscores why experiences of solidarity, interracially and across other dimensions of Power-ldentity are critical.

Similarly, when $A L P R$ organized its symposium on Africa and the Caribbean, I saw my Congresswoman, Barbara Lee, for the first time, and also listened to Congresswoman Cynthia McKinney speak. I found it especially powerful, given contemporary events, to hear them relate the history of the Congressional Black Caucus's decades-long struggle to protect voting rights and to change how the United States treats Haiti. ${ }^{189}$

In this letter I can only mention a few of the events and experiences that made me conclude that realizing one's action potential to become a multidimensional social justice advocate requires regular interaction in a community. In our case, this was the community of students, faculty, administrators, alumnae/i, and clerical and plant workers at Boalt. Without regular interaction, one cannot practice solidarity or accountability. This is the strange opportunity of law school and part of the reason law schools are such hotly contested spaces. Law schools are not only contested for the faculty, as critical race theorists have persuasively argued, and also for law students, as Duncan Kennedy articulated over twenty years ago. ${ }^{190}$

Transcending even Justice O'Connor's expansive definition of the compelling benefits of social diversity in higher education, sustained engagement with a critical mass of potential insurgent student activists is a process of subject formation that provides significant opportunities for people to orient away from the ideology of success (elite-designed yet mass-produced) that U.S. law schools commonly engender. By working together regularly, we, activist students, gain the experiences in which to ground alternative beliefs about what constitutes "the good life" and how to obtain it by creatively and ethically advocating for social justice in all its dimensions.

189. At the time of the symposium, the recent ouster of President Aristide had obscured the highly significant bicentennial of the liberation of Haiti by its former slaves, an unthinkable act to Eurocentric people, that nevertheless founded "the first independent modern nation state of the so-called Third World." See Michel-Rolph Trouillot, Silencing the Past: Power and the Production of History 34, 37, 68, 89, 94-95 (1995).

190. See, e.g., Crenshaw et al., CRITICAL RACE ThEORY, supra note 76, at xxii (discussing why "it is politically meaningful to contest the terrain and terms of dominant legal discourse" and noting that law schools are "an influential site for indoctrination and propagation"); see also Kennedy, supra note 67 , at 1 . While Kennedy's analysis may be flawed in some ways, e.g., it seems to presume an audience that uncritically self-identifies as male and racially White, I find his central critique of the social function of law schools useful. His basic argument is that law "schools are intensely political places ... [that provide] ideological training for willing service in the hierarchies of the corporate welfare state." 
With heart more old than the horn

That is brimmed from the pale fire of time. . ${ }^{191}$

Marc-Tizoc

\section{VII \\ Advancing The Asian American Movement At Boalt Hall (STEPHEN'S THIRD LETTER)}

Dear Marc-Tizoc and Rachel,

In reading and rereading your letters, my mind returns to two specific ideas. First, Rachel, I really enjoyed your summary of the shifts in the role of social justice in legal education. It reminds me that social movements are not always in pursuit of something-they can respond to cataclysmic ruptures in life.

The second idea concerns Marc's evocation of Grutter v. Bollinger and the idea that a critical mass of students of color is important to cultivating law students' intellectual and social development. ${ }^{192}$ The debates and discussions on campus during the months leading up to the Court's decision profoundly shaped my first year of law school, but until I read Marc's letter 1 had not thought much about it since then. For me, critical masses promise much more than lively classroom discussion. Indeed the Asian American Movement requires critical masses, not only to lend legitimacy to public institutions, but to provide for meaningful opportunities to build coalitions against racial tyranny.

With these ideas in mind, 1 would like to address my experiences at Boalt more specifically. As you recall, in my last letter, I outlined what I saw as the key struggles within Asian American Studies, and, admittedly, painted a fairly bleak contemporary picture. Now, l'd like to discuss some of the ways in which the Asian American Movement found expression during my three years at Boalt.

To do this, I would like to return to the Movement's fundamental principles, which as I see it, rests upon three core tenets: (1) the struggle of Asians in Ameriea is intimately linked to the struggles of the larger Third World; (2) any social goods (such as professional degrees) and material gains (sueh as increased wealth) derived as a result of the movement must be used at least in part to "serve the community"; and (3) the most effective and lasting method of social change results from coalitional organizing.

191. W.B. Yeats, The Poet to his Beloved, in W.B. Yeats, The Wind Among The Reeds (1899), reprinted in The Collected Poems of W.B. Yeats: A New Edition 63 (Richard J. Finneran ed., 1989).

192. See Marc's letter, supra. 


\section{A. Third World Struggle}

Nations and nationalism remains a thorny issue today amongst Asian American activists, intellectuals, and advocates generally. For example, the "perpetual foreigner" paradigm captures one major way in which antiAsian sentiments are given expression. And like its model minority twin, this narrative invites a visceral response of wanting to prove, at any cost, how "American" Asian Americans can be. To the question, "where are you from?" comes some form of the answer "1 am American-as American as you." But this response uncritically validates notions of "the nation" and "the citizen" by rejecting out of hand anything that lies beyond U.S. borders. This is a dangerous proposition given that citizenship has historically functioned to support White identity. ${ }^{193}$ For example, right now the United States is again wrestling with the "immigration" question, particularly along the southern borders, which really means it is wrestling with the "Latino" question.

Asian American anxiety over "the nation" emerged quite clearly within the Asian American Law Journal. Founded in 1993, the journal is one of two in the nation that centers on Asian American communities. Believing firmly that the Journal grew out of the Asian American Movement, 1 fought to ensure that whatever course Asian American scholarship embarked upon in the twenty-first century, our Journal would situate itself squarely as a Movement publication. Examine the first paragraph in the Journal's mandate:

Our mandate is to publish commentary, analyses, and research on the lives and struggles of Asian Pacific American communities. We believe that excellence in Asian American Critical Legal Scholarship demands nurturing scholarship that critically engages the project of anti-subordination as it concerns Asians in the Americas. Therefore, scholarship that either rejects anti-subordination struggle or else is limited in substance to Asians in Asia falls outside of our mandate. The gist of our mandate is to speak truth to power; to borrow from poet Janice Mirikitani: "We give testimony. Our noise is dangerous." 194

Though journal members could be persuaded of the historical and theoretical connections between the journal and the Movement in terms of issues arising within United States borders, fewer were willing to acknowledge the relevance of struggles beyond United States borders. Members often had to be reminded that the movement began as part of the Third World Liberation Front, whenever they rejected out of hand an article pertaining to issues arising in Asia.

193. See, e.g., Leti Volpp, The Citizen and the Terrorist, 49 UCLA L. REv. 1575 (2002).

194. See http://www.boalt.org/AALJ/. 
Leti Volpp, Boalt professor and Asian American Law Journal faculty advisor, puts it this way:

For Asian Americans, thinking critically about whether anti-subordination can be achieved through equality within the nation-state may help provide some recognition of the limits of liberalism. I would suggest that the Asian American desire for recognition as "American" is a fraught project that is frustrated by the way in which "Asian" and "American" have historically been posed as antithetical terms. I would argue as well that the desire for national belonging unnecessarily circumscribes claims for justice. The contemporary moment, post-September I1, sharply presents both the lure and the dangers of understanding equality within the nation as the limit of one's ambit of concern. ${ }^{195}$

I do not mean to suggest that the members' concerns were frivolous. Standing in the shadows of academic disciplines like East Asian or South Asian Studies, which commonly engage in colonial projects through the orientalist gaze, ${ }^{196}$ understandably left many members with a bad taste in thcir mouths. But the answer is not to erect intellectual borders and exalt American nationalism. Rather, to remain a Movement publication, we must commit to giving the Third World some expression in the journal's scholarship.

\section{B. Serving the Community}

Another core tenet of the Movement was using education to serve one's community. Of the three, this idea remains the most deeply democratic principle in concept and action. In concept, education was meant not simply to serve private interests at the highest levels of society, but to educate the masses about their rights and duties. Asian American and Ethnic Studies departments represented a commitment to the surrounding communities that provided the university with the labor and workforce to keep it operating. In action, this ideal also served as a warning. If institutions did not meet these public commitments, the people as a whole - and not just student populations-would organize and act. "The mass character of community struggles is the least appreciated aspect of ... [the Asian American] movement today," Asian American historian and activist Glenn Omatsu explains. ${ }^{197}$ Contrary to the popular belief that the movement was solely comprised of students, "high-school youth, tenants, small-business people, former prison inmates, former addicts, the elderly, and workers [all embraced] the struggles."198

195. Leti Volpp, Rethinking Asian American Jurisprudence, 10 AsIAN L.J. 51 , 55 (2003).

196. See, e.g., Edward W. SAID, OrIEnTalism (1978).

197. Omatsu, supra note 10, at 27 (emphasis original).

198. Id. 
In a law school setting, therefore, serving the community means that education-both the knowledge it provides and the legitimacy it affordsmust be used in a manner that is useful to surrounding communities and that furthers the project of antisubordination. Often times, this means providing actual services to outside communities. For example, the Asian Pacific American Law Students Association (APALSA) sponsors an informal immigration clinic, which is offered three times a month at various locations around the Bay Area. Boalt alum Joren Lyons, staff attorney at the Asian Law Caucus, acts as the supervising attorney. He and student volunteers assist indigent noncitizens with an assortment of immigration-related applications. Significantly, the clinic provides services to a wide range of clients, and not only to Asian American communities.

Other times, the principle to serve the community requires embarking on smaller projects for the purposes of community education. Jessie Warner (Boalt Class of 2005), Programs Editor for the then Asian Law Journal during 2004-05, put together a creative series of films entitled, "The Buried Past Film Series." The idea of the "buried past" derives from the late Yuji Ichioka, an Asian American historian and activist who analogized the task confronting Asian American scholars to seeking to recover the buried past. This film series sought to educate the Boalt student community on the various struggles the Asian American Movement had confronted and survived. That year's program coverage included the sixtieth anniversary of United States $v$. Korematsu, ${ }^{199}$ the Free Chol Soo Lee Movement, and an up-close and personal examination of incarcerated youth.

But the event in which I took the most pride as a student leader was $A A L J$ 's 2005 symposium. Entitled "Exiled Once Again," AALSs symposium focused on the legal and social consequences of Congress's draconian expansion of the category of deportable offenses.

The symposium grew out of a paper Gary Chow (Boalt Class of 2006), AALSs 2004-05 Symposium Editor, wrote to fulfill the final paper requirement for the class Asian Americans and the Law in the Spring of 2004. Gary expanded on that paper the following Fall in a journal writing seminar, which student leaders and allied faculty set up explicitly to develop papers-in-progress in order to provide our Power-Identity journals with bumper submissions; his piece was eventually published in $A A L J .^{200}$ As Gary assumed his leadership role within $A A L J$, the importance of his idea became apparent. The idea demanded a public delivery--hence, the birth of the symposium.

199. Korematsu v. United States, 323 U.S. 214 (1944).

200. See Gary Kar-Chuen Chow, Exiled Once Again: Consequences of the Congressional Expansion of Deportable Offenses on the Southwest Asian Refugee Community, 12 AsIAN L.J. 103 (2005). 
Regarding the event itself, three aspects of the day stand out, each of which contributed in unique ways towards the spirit of serving the community. First, $A A L J$ structured each panel so as to prevent lawyersmembers of the most prestigious and powerful profession attending-from occupying the spotlight's center. As a consequence, no single panel was comprised entirely of lawyers or law professors. Loan Dao, a doctoral candidate in UC Berkeley's Ethnic Studies department and a key organizer of the symposium, insisted that the symposium be set up in a way that demanded the participation of lawyers, nonlawyer activists, law students, and the public at large for each and every panel. This equality-based approach placed great weight on the idea of "community." Though education carries great cultural currency, its value does not require that the elites continually occupy the community's center. Rather, as Glenn Omatsu reminds us, "that people-not the elites-make history." "201

A second way in which $A A L J$ sought to fulfill this principle was to make the symposium accessible to a wide number of people by making admission free. We were only able to do this through the contributions of various local offices of nationally recognized law firms. This was a difficult decision, primarily because receiving contributions always risks conceding too much. Often the greatest price to be paid by the oppressed is the loss of autonomy.

A third and final way in which $A A L J$ effectuated the spirit of the Movement was to embrace the privilege we all possessed. Whether we decided to support or subvert power, we as a part of Boalt Hall were a potential instrument of the powerful. Therefore, we took seriously our status as a student group at the flagship law school of the nation's most prestigious public school system, and recognized that we could use this status to support one of the most marginalized and just causes of the last thirty years.

This is not to say that our execution of the symposium left no room for improvement. For example, halfway through the day of the symposium, several members noticed that male members tended to occupy managerial and public positions, such as directing attendees and greeting panelists, while female members tended to fulfill secondary and private duties, such as setting up and cleaning up. In our postsymposium meeting, the organizers acknowledged this sloppy praxis; the take-away lesson here is that true change requires sustained engagement by its participants.

\section{Coalitional Organizing}

The last core tenet of the Asian American Movement is the commitment to coalitional politics. As activist old-timer Steve Louie

201. Omatsu, supra note 10 , at 21. 
explains, "One of the hallmarks of the Asian American Movement was to 'unite all who can be united,' whether that was within the Asian community or with other communities, especially people of color."202

From your letters, you two clearly believe that coalition building prevailed as the dominant form of student activism during our time at Boalt. Though I agree that it certainly constitutes the most effective method of achieving change, from my experience, it did not prevail as a dominant mode of change at least among Asian Americans. Throughout my time at Boalt, Asian Americans seemed uninterested in coalition building. Perhaps Asian Americans have become comfortable as the largest racial minority group in the law school.

But the price of forgoing the opportunity to build meaningful, longterm relationships across racial lines is too high, and not just in aspirational terms. Material harms also ensue. Claire Jean Kim makes an outstanding observation on this point. Under the modern framework, Asian Americans, in their attempt to resist White supremacy, actually contribute to the project of Black subordination. The current framework, Kim points out, is "anchored by the Civil Rights Act of 1964 and the Voting Rights Act of I965,"203 the crown jewels of the Civil Rights Movement. Here, the ostensibly neutral state actor metes out relief to the "minority deserving remedial aid," 204 challenging Asian Americans to prove that they are, in Kim's words, bona fide minorities, victimized by historical and continuing discrimination. But not all minorities are the same, at least not in all instances. It borders on hubris for Asian Americans, in most educational contexts, to claim they are victims of racial discrimination under affirmative action programs designed to benefit Blacks, Latinos, and Native populations. And at the same time, it constitutes nativist racism for Blacks to support anti-immigrant laws, such as Proposition 187.

One important exercise in the praxis of coalitional politics at Boalt was the community education project to commemorate the fortieth anniversary of Lau v. Nichols. ${ }^{205}$ Two thousand and four commemorated the thirtieth anniversary of Lau, which held that the San Francisco Unified School District's denial of bilingual education to Chinese American students violated the Civil Rights Act of 1964. At this event, we tapped our law school faculty and alumni resources. Professor Stephen Sugarman, who had participated in the litigation of Lau, provided a discussion of the history surrounding the case. Professor Rachel Moran, a renowned scholar and author of a casebook on educational law, provided an analysis of Lau's

202. Steve Louie, When We Wanted It Done, We Did It Ourselves, in Asian Americans: the Movement And the Moment xv (Steve Louie \& Glenn K. Omatsu eds, 2001).

203. Kim, supra note 116 , at 41 .

204. Id. at 42 (emphasis added).

205. 414 U.S. 563 (1974). 
continuing vitality, ${ }^{206}$ and Deborah Escobedo (Boalt Class of 1979) provided a glimpse into contemporary bilingual education law from a practitioner's perspective.

The event was important because it demonstrated that personal relationships matter in the exercise of coalition building. The entire project greatly benefited from the personal friendship 1 share with Marc-Tizoc, if for no other reason than we trusted one another and therefore were able to act efficiently. And it provided an important parallel story to Brown $v$. Board of Education, which celebrated its fiftieth anniversary in 2004, and hence drew much of the year's attention from legal scholars. While Black communities continue to occupy the center of this country's race narrative for obvious and important reasons, my personal social justice ethic demanded foregrounding that they need not stand alone.

Anyway, these are some thoughts I'm wrestling with. My time as a student is finished, so 1 hope to see the Movement continue along the paths that $A A L J$ carved out during my tenure at Boalt.

Take good care,

Stephen

\section{VIII}

SCHOLARSHIP AS ACTIVISM

(RACHEL'S THIRD LETTER)

Dear Marc-Tizoc and Stephen,

Student-run law journals are a potential site for students to engage in and shape social justice praxis and critical race praxis within the law school. Students involved in the running of scholarly legal publications have an opportunity to (1) facilitate the development and application of theory within the antisubordination struggles of racial communities, (2) emphasize practical concepts of social justice for specific ethnic and racial communities, and (3) encourage interracial praxis. ${ }^{207} \mathrm{In}$ this, my final letter, I focus on my experiences with social justice praxis in and among student-run law journals at Boalt.

206. See e.g., Rachel F. Moran, Undone by Law: The Uncertain Legacy of Lau v. Nichols, 16 Berkeley La Raza L.J. I (2005).

207. See Yamamoto, Critical Race Praxis, supra note 65, at 830 . 
Boalt is currently home to eleven student-run academic journals. ${ }^{208}$ Of these, student publications such as the Berkeley Journal of AfricanAmerican Law \& Policy, the Asian American Law Journal, the Berkeley Journal of Gender, Law \& Justice, a continuation of Berkeley Women's Law Journal, and the Berkeley La Raza Law Journal expressly welcome intellectual exchanges that do not omit or whitewash the roles of race, gender, sexual orientation, and disability in American law. The presence of multiple identity and specialized student-run law journals at Boalt presents valuable opportunities for social justice and critical race praxis and coalitional race-plus activism. In this letter, I (I) briefly narrate the story of their establishment, (2) examine the role of community-focused journals at Boalt, and (3) share some examples of coalitional social justice praxis.

The first of these four journals, the Berkeley La Raza Law Journal, is the longest running Latina/o law journal in the country. ${ }^{209}$ It was established as the La Raza Law Journal in 1981, two years before the faculty hired its first Latina, Professor Rachel Moran, and seven years before the faculty hired its first Latino, Professor Dan Rodriguez. BLRLJ'S mandate is to "provide a forum for the analysis of pressing legal and social issues affecting the Latino community" legislators, stir the conscience of judges, and provide a dynamic tool for practitioners concerned with the impact of their work on the Latina/o community." " Despite the growing Latina/o population in the United States, at the turn of this century it remained one of only five such journals in the country. 212

The second of these journals, the Berkeley Journal of Gender, Law \& Justice, was conceived as the Berkeley Women's Law Journal in 1983 as the third academic women's law journal in the country. ${ }^{213}$ Its first volume

208. In 2005, eleven student-edited journals were in publication at Boalt. They published their first volumes as follows: California Law Review (1912), Ecology Law Quarterly (1971), Industrial Relations Law Journal (1976) [renamed Berkeley Journal of Employment and Labor Law (v. 14, 1993)], La Raza Law Journal (Spring 1983) [renamed Berkeley La Raza Law Journal (v. 12, Fall 2001], International Tax and Business Lawyer (Summer 1983) [renamed Berkeley Journal of International Law (v. 14, 1996)], Berkeley Women's Law Journal (1985) [renamed Berkeley Journal of Gender Law \& Justice (v. 20, 2005)], High Technology Law Journal (1986) [renamed Berkeley Technology Law Journal (v. 11, 1996)], Asian Law Journal (Oct. 1993) [renamed Asian American Law Journal (v. 13, 2006)], African-American Law \& Policy Report (1994) [renamed Berkeley Journal of African-American Law \& Policy (v. 8, 2006)], California Criminal Law Journal (2000) [renamed Boalt Journal of Criminal Law (v. 7, June 2004)], and Berkeley Business Law Journal (2004). Herma Hill Kay, Berkeley Women's Law Journal: A Powerful Force at Twenty, 20 BerKeley J. OF Gender L. \& Just. 1,1 n.2, 6 n.37 (2005).

209. Perez \& Smith, supra note 60 .

210. Ann Marie Mitre \& Evangeline Maria Nichols, Introduction, 2 LA Raza LJ. (1988) (unpaginated); Ilene Garcia \& Eileen Trujillo, 3 LA RAZA L.J. (1990) (unpaginated).

211. Perez \& Smith, supra note 60 . (unpaginated).

212. Arrona \& del Peral, supra note 83 (unpaginated).

213. Herma Hill Kay, Berkeley Women's Law Journal: Ten Years of Giving Voice to Underrepresented Women and Their Concerns, 10 BERKELEY WOMEN's L.J. 1, I (1995). 
was published sixty-four years after Professor Barbara Nachtrieb Armstrong joined the Boalt faculty in $1919^{214}$ and two years after Sandra Day O'Connor became the first woman appointed to the United States Supreme Court. ${ }^{215}$ BGLJ's mission has evolved over time and, shortly before the passage of Proposition 209, was revised to focus on "mov[ing] issues concerning traditionally underrepresented women from a marginalized position in legal discourse to the center of discussion."216

The third of these journals, the Asian American Law Journal, was founded as the Asian American Law Journal in 1991, forty-one years after Professor Sho Sato became the first Asian American member of the Boalt faculty and fifty-years after a second-year student was "evacuated as a Japanese."217 It aimed to "provide a voice for the many diverse Asian American communities which had heretofore been excluded from traditional, non-race-conscious legal scholarship."218 An article by Robert S. Chang, published in both $A A L J$ and $C L R$ in 1994 , first announced the Asian American Movement in the legal academy. ${ }^{219}$

The fourth of these journals, the Berkeley Journal of AfricanAmerican Law \& Policy, was created in 1992 as the African-American Law \& Policy Report, four years after Boalt's first and, as of 2005, only Black female professor was hired and twelve years before Christopher Edley, Jr. became dean of Boalt. In the first volume of $A L P R$, the foreword refers to the proposal for Proposition 209, which had not yet been passed, as an example of the reinforcement of social stratification through so called "colorblindness" that underscores the need for journals of color. ${ }^{220}$

Achieving a sustainable interracial praxis requires first admitting and accepting that race is an element of defining each persons margins of difference. Such journals aim not only to publish scholarship by, for, and about underrepresented or alienated groups, but also to "transform the law school and even legal education itself." 221 By fostering and encouraging scholarship from "people who are close to the problem," 222 these journals

214. Herma Hill Kay, The Future of Women Law Professors, 77 lOWA L. REV. 5 (1991).

215. Karen Berger Morello, The Invisible Bar 218 (1986); James Evans, $A$ Woman at the Helm, S.F. Dally J., Mar. 17, 1992, at 1, 2.

216. Editorial Page, 9 Berkeley WoMEN's L.J. (1994) (unpaginated).

217. EPSTEIN, supra note 20, at 181 (citing Minutes of Faculty, School of Jurisprudence, April 16, 1942).

218. Editor's Note, 2 Asian L.J. (1995) (unpaginated).

219. Robert S. Chang, Toward an Asian American Legal Scholarship: Critical Race Theory, Poststructuralism, and Narrative Space, 81 CALIF. L. Rev. 1241 (1993); Robert S. Chang, Toward an Asian American Legal Scholarship: Critical Race Theory, Post-structuralism, and Narrative Space, 1 AsIAN L. J. 3 (1994).

220. Jerome MeCristal Culp, Jr., Frank Cooper \& Lovita Tandy, Foreword, A New Journal of Color in a "Colorblind" World: Race and Community, 1 AFr.-AM. L. \& PoL'Y REP. I, 2 (1994).

221. Hill Kay, supra note 208, at 4.

222. Anna Bannerman-Richter et al., Reflections on the Birth of the Journal: A Founders' Roundtable Discussion, 20 Berkeley J. Of Gender L. \& Just. 12, 17 (2005). 
can promote the dissemination of experiences and insights that are characterized by margins of difference rather than whitewashing those margins. In addition to contributing to the development of scholarship, they also enrich the academic discourse by regularly sponsoring speakers addressing their target communities' issues and concerns while attempting to avoid assumptions traditionally made in the predominantly White, male, straight, physically-abled legal pedagogy.

These journals often rely on solidarity with their sister organizations to fulfil their mandates such as the Asian Pacific Law Students Association, the Berkeley Women's Association, La Raza Law Students Association, and the Law Students of African Descent. Coalitional efforts with their sister organizations promote social justice praxis and critical race praxis by strengthening the link between scholarship and practice, and between law students whose interests focus on specific communities and the communities they represent.

While student-run legal journals often serve as a "refuge from an atmosphere that [can be] intellectually inhospitable, even alienating, for women"223 and underrepresented minorities, they also function as "an empowering stroke of retaliation against marginalization and a beacon of hope for . . law students everywhere." 224 White men have dominated the discourse in most areas of legal scholarship and education, but a critical mass of scholars from "outsider" communities has allowed students and professors to engage in public debates that do not require the permission, approval, or participation of the dominant legal culture. These discussions historically occurred behind closed doors, and bringing the conversation into the public sphere finally enabled social-justice oriented scholars and activists to move beyond talking about what everyone already knew. Identity groups defined the discourse or issues within their communities, but these self-identified communities also invited others into this space to engage with issues with which they were less familiar. This resulted in parallel and overlapping intellectual exchanges. The resulting shifts in assumptions allowed us to apply novel analyses of interrelated issues and find new solutions to common concerns. For example, this "intersection of critical analysis" 225 has resulted in numerous cosponsored events and joint publications, as well as this epistolary.

The presence of multiple identity journals at Boalt creates an institutional structure that facilitates the development of an interracial praxis. ${ }^{226}$ Identity journals form issue-defined coalitions to apply

223. Hill Kay, supra note 208 , at 4 .

224. Id.

225. Arrona \& del Peral, supra note 83 (unpaginated).

226. Interracial praxis "acknowledges continuing white dominance in many spheres of socioeconomic life and expands justice inquiry beyond white on black and even white on color to encompass color on color." Yamamoto, Critical Race Praxis, supra note 65, at 830. 
specialized theory, analyses, and insights and focus on specific aspects of interminority justice. This type of coalition allows a exchange that incorporates the values of communities as well as individuals. It also avoids forcing individuals into the position of standing in as a representative for an entire ethnic group. ${ }^{227}$ At Boalt, some coalitions were formed out of necessity in response to the crises arising out of the effects of SP-1 and Proposition 209 and others resulted from a desire to realize the synergies and benefits achievable through intergroup and interracial praxis.

As was the case for the other student-of-color journals, the elimination of race-conscious admissions at Boalt had a substantial effect on ALPR's ability to maintain a regular publication schedule. The second and fourth volumes of the African-American Law \& Policy Report were published in the spirit of cooperation that had characterized the Black Law Journal $(B L J) .{ }^{228}$ However, whereas $B L J$ was published in collaboration with other law schools, these joint volumes were published in cooperation with other journals at Boalt Hall. Volume two was a joint effort with the Berkeley Women's Law Journal, and volume four was published in cooperation with the La Raza Law Journal. For $A L P R$, "publishing is an act of resistance to forces like Proposition 209 that would, if left unchecked, permanently alter the composition and quality of our institution."229

In the Spring of 2004, $A L P R, A A L J, B L R L J, B W L J$, and $C L R$ agreed to publish a collaborative symposium issue in connection with the Brown v. Board of Education Symposium sponsored by CSJ. While working together on this cross-journal effort that all of the journals saw as central to their mandate, we had an opportunity to share the goals and cultures of our respective journals and to learn about those of our peer journals. It required an "immense commitment from each journal's membership to a process that [was] much more intense than that of publishing a regular volume."230

The editors of BLRLJ summarized the key to the success of this coalitional process when they wrote "true coalitional work requires vulnerability and a willingness to have the tough conversations needed to bridge differences toward a common aim." ${ }^{231}$ Although an all-female group

227. Here I am thinking of the many instances where, for example, a lone Black student in a classroom or organizational setting is forced to choose between the impossible task of attempting to speak for all Black people in the United States or to allow no perspective from a Black person to be represented at all. The middle ground of simply representing their own individual perspective as a Black person is, if one is the only Black person in the room, in practice often not a realistic possibility.

228. In 1987, for the first time in its history, the National Black Law Journal (formerly the Black Law Journal) published a UCLA/BoaIt Hall Joint Edition to symbolize a commitment to a nationwide unification of the effort to improve the lot of the Black community.

229. ALPR Editors in Mary Louise Frampton, supra note 60, at 130.

230. Lagarda \& Valverde, supra note 60.

231. Id. at xii. "[A]n interracial praxis explores prospects of intergroup healing and assesses racial group agency and responsibility both enlivened and constrained by multiple contexts." Yamamoto, Critical Race Praxis, supra note 65, at 830. 
attended almost all coordinating meetings and everyone at the meetings was interested in promoting social justice, we had to work hard to identify the common ground in our differing perceptions with regards to process, substance, form, and just about everything else. But all of our "grappling with issues of race, class, and gender in a cross-journal coalitional effort" 232 was worth it. In the end, "[t]his collaboration represents an affirmative step ... by creating meaningful social change in the spirit of Brown"233 and "[w]ithin our community of Boalt Hall, this collaboration also represents an important step toward building meaningful, lasting coalitions among identity groups and journals." 234 At the same time, we aspired to reach beyond the walls of the law school and legal education and "contribute to a dialogue about continuing Brown's promise into the future."235

During our time as law students, we, along with other Boalt students and professors, witnessed, experienced, and resisted the effects of the dramatic demographic shift at Boalt due to the "race neutral" resegregation of higher education in California under Proposition 209, and other social stresses. ${ }^{236}$ Student scholars and law journal members were on the front lines and many understood themselves to be part of the new student insurgency and the emerging shift in social justice theory and practice that you mention in your earlier letters, infra, Marc. I hope and believe that the lessons we learned as student activists at Boalt about people, power, solidarity, coalitions, and interracial praxis will inform us in our careers and make us better people, lawyers, representatives of our communities, and members of society as a whole.

Sincerely,

Rachel

IX

DEMOCRACY AND FASCISM

(MARC-Tizoc's THIRD LETTER)

Querida/o Rachel y Stephen,

At the end of our epistolary, I want to draw your attention beyond social justice theory or student activism in U.S. law schools to the broader

232. La Raza Editors in Foreword, supra note 60, at 131.

233. AALJ Editors in Foreword, supra note 60, at 130.

234. BWLJ Editors in Foreword, supra note 60, at 131

235. CLR Editors in Foreword, supra note 60, at 132.

236. For further discussion of the social stresses of the Reagan-era and the neoconservative counter-revolution, see OMI \& WINANT, supra note 65 and John O. Calmore, Exploring Michael Omi's "Messy" Real World of Race: An Essay for "Naked People Longing to Swim Free", 15 LAW \& INEQ. 25 (1997). 
historical moment in which we now live. Experiencing our student insurgency at Boalt caused me to imagine myself in profound solidarity with people across many dimensions of Power-Identity throughout the world, and experiencing this subjectification on the cusp of our entry into the professional world of law seems especially relevant given the current historical moment, which seems marked by a revolution in democracy and fascism. ${ }^{237}$

\section{A. The Insurgent Future (Past)}

Naming contemporary student activism at U.S. law schools the new student insurgency feels useful because the concept may refresh our understanding of the radical potential of student power across and beyond the United States. Additionally, when the Bush regime has exerted U.S. hegemony to redefine words like "coalition" and "insurgency," I feel compelled to dispute its power to define the people's resistance. As you recall, within our first year at Boalt, after U.S. military forces had invaded Afghanistan, the Bush Administration promulgated and the media echoed the notion that a "coalition of the willing" had agreed to invade Iraq as part of the perpetual and world-wide "War on Terror."238 The Bush Administration's "Newspeak," however, deeply troubled me. ${ }^{239}$ Having joined LRLSA, the Journal, and the Coalition and found them highly meaningful spaces of multidimensional solidarity in service to broad antisubordination goals, the Bush Administration's usurpation of the term "coalition" inspired me to understand the political history of the term and why gente de corazón (people of "good heart," connoting courage, compassion, and emotional intelligence) should contest its new official definition.

Similarly, hearing media reports about "Iraqi insurgents" triggered memories of my adolescent attempts to understand the first U.S. invasion of Iraq and historically proximate events like Perestroika, the fall of the Berlin Wall, the end of Apartheid in South Africa, the violent repression of student protest in Tiananmen Square, and the overthrow of Marcos's

237. For people who are interested in gleaning insights into contemporary transnational politics by remembering and understanding historical fascist regimes, I highly recommend Umberto Eco, UrFascism, in Umberto Eco, Five Moral Pieces, 65-88 (1997). People interested in reflecting on democracy in the United States should consider arguments advanced in ANGELA Y. Davis, ABOLITION Democracy: Beyond Empire, Prisons, and Torture (2005); and Cornel West, Democracy Matters: Winning The Fight Against Imperialism (2004).

238. See, e.g., Steve Schifferes, US Names "Coalition of the Willing", BBC NEws, Mar. 18, 2003, http://news.bbc.co.uk/2/hi/americas/2862343.stm. The "War on Terror" has been variously named the "War against Terror" and the "War against Terrorism." Analyzing the permutations of the label is beyond the scope of this essay.

239. On Newspeak, see George Orwell, Nineteen-eighty Four 298-99 (1949) ("The purpose of Newspeak was not only to provide a medium of expression for the world-view and mental habits proper to the devotees of Ingsoc, but to make all other modes of thought impossible.'). 
regime in the Philippines. As I pursued these threads of memory, I recalled that I had last heard the term insurgent used by U.S. media reports about the Contras y Sandistas in Nicaragua and related U.S. interventions into Latin America, like the mission to "rescue" Panama (and its canal) from its formerly U.S.-supported dictator, Manuel Noriega. ${ }^{240}$

I thus composed my counter-memory of Raza student activism at Boalt, sensitized to Third World histories of resistance to domination and having recently returned from my own visit to Chile, Argentina, and South Africa, ${ }^{241}$ I came to believe that thinking about and calling our organized student activism an insurgency could usefully represent our coalitional solidarity and might also help us understand our relationships with contemporary student power movements and the transnational history of student activism, such as in México and France in $1968 .{ }^{242}$ In turn, I braided my understanding of the importance and violent repression of student dissent at the end of the twentieth century with my knowledge about the history of French resistance against (and complicity with) the Nazi regime of Germany. This history profoundly affected me when 1 first learned of it as a high school student and also informed me throughout my adolescence and young adulthood, whenever I confronted the neo-Nazi skinhead youths who had established several gangs in my hometown of Sacramento, California.

In the dawning twenty-first century, people may or may not identify with these and other social justice struggles. In U.S. law schools, remembering historical struggles and engaging current ones can be understood as insurgent acts, and by these acts law students practice becoming the social justice advocates needed to intervene effectively within the contemporary hegemony. It is all too easy to become complicit in the institution's "training in hierarchy." Yet, oppressed and exploited communities can benefit greatly from educated people who apprehend the multidimensionality of the current hegemony, know its inter/national history of subordination and collective resistance, and choose daily to struggle toward the "abolition of every possibility of oppression \& exploitation," starting with the community in which they live. ${ }^{243}$

While our individual sacrifices and actions are relatively unimportant, they are necessary for us to act collectively and creatively as multidimensional social justice advocates. Together, we may transcend mere political lawyering and help create new ways for people to live and

240. CNN.com, Noriega back in Prison after Stroke, CNN.com, Dec. 6, 2004, http://edition.cnn.com/2004/US/12/06/noriega.stroke/index.html.

241. See supra note 88 and accompanying text

242. See Wikipedia: The Free Encyclopcdia, Tlatelolco massacre, http://en.wikipedia.org/ wiki/Tlatelolco_massacre (last visited June 30, 2006); Wikipedia: The Free Encyclopedia, May 1968, http://en.wikipedia.org/wiki/May_1968 (last visited June 30, 2006).

243. Kelley, supra note 63, at 79, 102. 
conduct sustainable community change. We can braid our efforts into existing networks of social justice advocacy and disrupt the current hegemony long enough to institute ways of being that do not presume (justify) the inevitable (consumer capitalist) destruction and exploitation of life. $^{244}$ I will end by making three brief observations about our contemporary moment.

\section{B. El Momento Revolucionario}

I call the moment revolutionary for three main reasons. First, in the dawning millennium, we have witnessed the Bush regime declare a perpetual "War on Terror," putatively in response to the escalation of nonstate violence by "terrorists" and "enemy combatants." As you both know, Rachel and Stephen, the Bush regime complemented its invasion of Afghanistan and Iraq with an assault on human rights in the United States. In our first semester at Boalt, the federal government demanded the "special registration" of resident immigrants from certain nations, which is chillingly redolent of the World War II internment of hundreds of thousands of immigrants from Japan and their U.S.-born children and the $1930 \mathrm{~s}$ and 1950s deportation of hundreds of thousands of peopleregardless of their U.S. citizenship-who were racialized as "Mexican."245

Second, in this same period the U.S. Supreme Court denied the constitutionality of vote recounts, but affirmed the constitutionality of affirmative action programs in higher education and repudiated the state criminalization of homosexuality. ${ }^{246}$ It also struck down the Bush regime's "enemy combatant" designation of U.S. citizens and affirmed the venerable right of habeas corpus. ${ }^{247}$

Third, and finally, we are witnessing democracy and fascism resurge unevenly across the globe. For example, in December 2005, the people elected Evo Morales as the first Bolivian president to identify as indigenous (Aymara) since the conquistadores' destruction of the indigenous nations and European colonization. ${ }^{248}$ In March 2005 the people

244. While I lack the space to elaborate about the exciting community lawyering projects I've engaged since graduating from law school or to weave a hopeful story about the encouraging developments in the National Lawyers Guild's United People of Color Caucus, the National Latina/o Law Student Alumni Association, the Berkeley Law Foundation, and the Equal Justice Society, I want to name these organizations (and community lawyering) and encourage interested students to learn more about them.

245. See Ex parte Endo, 323 U.S. 283 (1944); Korematsu v. United States, 323 U.S. 214 (I944); Yasui v. United States, 320 U.S. 1 I5 (1943); Hirabayashi v. United States, 320 U.S. 81 (1943); Johnson, supra note 95 , at 660-70.

246. See Bush v. Gore, 531 U.S. 98 (2000); Grutter v. Bollinger, 539 U.S. 306 (2003); but see Gratz v. Bollinger, 539 U.S. 244 (2003); see also Lawrence v. Texas, 539 U.S. 558 (2003).

247. See Hamdi v. Rumsfeld, 542 U.S. 507 (2004); and Rasul v. Bush, 542 U.S. 466 (2004).

248. See Leftist Claims Victory in Bolivia, BBC NEws, Dec. 19, 2005, http://news.bbc.co.uk/2/hi/americas/4539454.stm (last visited Feb. 13, 2006); Bolivia's New Leader 
of the former Soviet Union republic of Kyrgyzstan opposed its flawed parliamentary elections to such an extent that they drove the putatively elected president from power. ${ }^{249}$ In both these regions, these highly democratic activities were not anomalous but instead representative of regional developments. ${ }^{250}$ ln marked contrast, the 2004 U.S. Presidential elections again featured significant disenfranchisement, often of people of color. Although a report authored by the House Judiciary Committee Democratic Staff substantiated this disenfranchisement, the mainstream media largely ignored it. ${ }^{251}$

These are the main events with which 1 frame the end of our epistolary. 1 hope to contextualize the recent past and ground our memories in the image of a revolutionary moment. By revolutionary, however, 1 do not mean an eternal break with the past. I do not believe that the end of the second Christian millennium coincided with a radical break or rupture with history. ${ }^{252}$ Indeed, I eschew one of the basic conceits (flaws) of Eurocentric postmodernism and mean to repudiate the peculiar "imperial amnesia" seemingly common in the United States. ${ }^{253}$ Rather, by calling the moment

Vows Change, BBC NEws, Jan. 22, 2006, http://news.bbc.co.uk/2/hi/americas/4636190.stm (last visited Feb. 13, 2006).

249. See Eurasianet.Org, Akayev Administration Collapses in Kyrgyzstan, Sending Tremors across Central Asia (2005), http://www.eurasianet.org/departments/civilsociety/articles/eav032405.shtml (last visited Feb. 13, 2006); Jeremy Page, Opposition Seize Second City in Kyrgyzstan Election Revolt, Times ONLINE, Mar. 22, 2005, http://www.timesonline.co.uk/article/0,3-1536190,00.html (last visited Feb. 13, 2006).

250. See Ian MacWilliam, Changing Winds in Ex-Soviet Lands, BBC News, Nov. 2, 2005, http://news.bbc.co.uk/2/hi/asia-pacific/4400716.stm (last visited Feb. I3, 2006); Jeremy Page, Times Online, Poll Protest in Kyrgyzstan Echoes Orange Revolution, Times OnLine, Mar. I6, 2005, http://www.timesonline.co.uk/article/0,3-1527049,00.html (last visited Feb. 13, 2006).

251. See, e.g., U.S. Rep. John Conyers, Jr., Ohio Voting Problems Show Need for Election Reform, ThE DETROIT NEws, Jan. 7, 2005, available at http://www.house.gov/ judieiary_democrats/ohvoteproblemsdetnewsI705.pdf (last visited Feb. I3, 2006); U.S. HouSE Judiciary Comm. Democratic Staff, Preserving Democracy: What Went Wrong in Ohio 4 (2005), available at http:/www.house.gov/judiciary_democrats/ohiostatusrept1505.pdf (last visited Feb. 13, 2006) (report requested by Rep. John Conyers, Jr., Ranking Democrat on the House Judiciary Committee, noting, "With regards to our factual finding, in brief, we find that there were massive and unprecedented voter irregularities and anomalies in Ohio. In many cases these irregularities were caused by intentional misconduct and illegal behavior, much of it involving Secretary of State $J$. Kenneth Blackwell, the co-chair of the Bush-Cheney campaign in Ohio."); THE CENTURY Foundation, Voting in 2004: A Report to the Nation on America's Voting Process 5 (2004), available at http://www.civilrights.org/campaigns/election_reform/12_7_ereform_summary.pdf (last visited Feb. 13, 2006) (noting, "Although the apparent margin of victory in this election and the way the media reported on it have led most people to believe the outcome is not in question, those who actually observed and were involved in this election believe it was highly flawed.").

252. Cf. Frederic Jameson, Postmoderism, or the Cultural Logic of Late Capitalism, 140 NEw LEFT REV. 59 (1984) (critiquing early proponents of postmodernism who claimed it involved a radical break with the past and historicizing postmodernism within the evolution of capitalism).

253. On postmodernism, see generally Robert F. BERKHOFER, BEyond THE GREAT StORY: History AS TEXT AND DiscourSe (1995); and Jameson, supra note 252. For a succinct critique of postmodernism as Eurocentric from an eminent post-colonialist scholar, see KWAME ANTHONY Appiah, In My Father's House: Africa in the Philosophy of Culture 119-24 (1992) 
revolutionary, like naming contemporary student activism insurgent, I focus our attention on the cycles of time and highlight how the past incompletely touches and shapes - in complex and often-obscure waysthe present and future. 1 use "revolutionary" to explain how I perceive our moment to be different from, and yet connected to, the worldwide yet ofthidden countertradition of student activism - a vibrant and critical praxis that has served the people well in the past and has the potential to do so now. ${ }^{254}$

I articulate our experiences at Boalt as part of a new student insurgency to distinguish our revolutionary historical moment while tracing its web-like connections to past moments of radical student activism. Ultimately, by collaborating with you to produce this critical race narrative, in the form of an epistolary, I aspire to record with you a counter-memory of the resurging student activism at Boalt and to inspire others' struggles for social justice with knowledge of our momentary iridescence. ${ }^{25 s}$

With love in my heart,

Marc-Tizoc

$\mathrm{c} / \mathrm{s}$

(contrasting the postcolonial and the postmodern). On the concept of "imperial amnesia," see Mathew Frye Jacobson, Imperial Amnesia: Teddy Roosevelt, the Philippines, and the Modern Art of Forgetting, 73 Radical History Rev. 116 (1999).

254. See, e.g., Wikipedia: The Free Encyclopedia, 2006 Labor Protests in France, http://en.wikipedia.org/wiki/2006_labor_protests_in_France (last visited June 30, 2006).

255. On critical race narratives, see generally Delgado, supra note 9; see also Lowe, supra note 69 (discussing Asian American and other alternative narratives). On counter-memory, see generally LiPSITZ, supra note 73 . 